\title{
는 \\ Measuring Happiness in Adolescent Samples: A Systematic Review
}

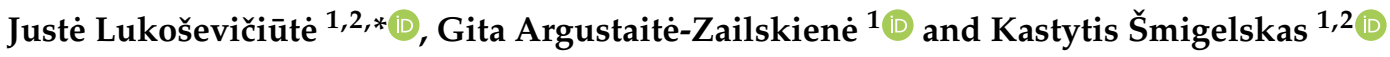 \\ 1 Department of Health Psychology, Faculty of Public Health, Medical Academy, Lithuanian University of \\ Health Sciences, Tilžès g. 18, LT-47181 Kaunas, Lithuania; gita.argustaite-zailskiene@lsmu.lt (G.A.-Z.); \\ kastytis.smigelskas@lsmu.lt (K.Š.) \\ 2 Faculty of Public Health, Health Research Institute, Medical Academy, Lithuanian University of Health \\ Sciences, Tilžès g. 18, LT-47181 Kaunas, Lithuania \\ * Correspondence: juste.lukoseviciute@lsmu.lt; Tel.: +370-37-242908
}

check for updates

Citation: Lukoševičiūtè, J.; Argustaitè-Zailskienè, G.;

Šmigelskas, K. Measuring Happiness in Adolescent Samples: A Systematic Review. Children 2022, 9, 227.

https://doi.org/10.3390/

children 9020227

Academic Editor: Sune Bo

Received: 18 January 2022

Accepted: 5 February 2022

Published: 8 February 2022

Publisher's Note: MDPI stays neutral with regard to jurisdictional claims in published maps and institutional affiliations.

Copyright: (C) 2022 by the authors. Licensee MDPI, Basel, Switzerland. This article is an open access article distributed under the terms and conditions of the Creative Commons Attribution (CC BY) license (https:// creativecommons.org/licenses/by/ $4.0 /)$.

\begin{abstract}
Background: Happiness is a phenomenon that relates to better mental and physical health and even longevity. There has been an increase in surveys assessing subjective well-being as well as happiness, one of the well-being components that reflect one's feelings or moods. Happiness is mostly measured in adult samples. There is a lack of an overview of the tools used to evaluate adolescent happiness, so this paper aimed to review them. Methods: A literature search was performed in the PubMed and PsycArticles databases (2010-2019). In total, 133 papers met the eligibility criteria for this systematic review. Results: The results are grouped according to the type of measure, single or multiple items, that was used in a study. Almost half of the studies (64 of 133) evaluated subjective happiness using single-item measures. The most commonly used scales were the 4-item Subjective Happiness Scale and the Oxford Happiness Questionnaire. Among the 133 articles analyzed, 18 reported some validation procedures related to happiness. However, in the majority of cases (14 studies), happiness was not the central phenomenon of validation, which suggests a lack of happiness validation studies. Conclusions: Finally, recommendations for future research and for the choice of happiness assessment tools are presented.
\end{abstract}

Keywords: happiness measurement; adolescent; mental health; systematic review

\section{Introduction}

Being happy is the goal of many people's lives. Interest in the phenomenon of happiness has been observed since ancient times. It is acknowledged that the philosopher Aristotle was the first to raise questions in the philosophical literature as to how happiness may best be understood [1]. Later, scientists in the field of philosophy defined happiness as "the belief that one is getting the important things one wants, as well as certain pleasant affects that normally go along with this belief" [2] (p.178). In 1999, Lyubomirsky and Lepper [3] proposed a different perspective on happiness, naming it "subjective happiness", which is currently defined as the individual's perception of being a happy or unhappy person [4].

During the last few decades, there has been a growing interest in positive psychology, especially concerning subjective well-being or happiness. Studies show that happiness can be influenced by both personal and external factors. The World Happiness Report [5] names income, work, community and governance, values, and religion as external factors, while mental and physical health, family experience, education, gender, or age may be regarded as personal factors.

Recent studies show that the relationship between happiness and health is developing rapidly, exploring the possibility that impaired happiness is not only a consequence of illness and health but also a potential risk factor [6]. The mechanisms potentially linking happiness with health include lifestyle factors, such as physical activity and nutrition [6]. 
A large-scale nationwide general population survey in China by Tan et al. [7] confirmed that happiness is associated with subjective health assessment and is more important with increasing age. Recent longitudinal research indicates that higher levels of happiness have numerous important health advantages, such as the reduced risk of mortality or morbidity in adults [6]. Moreover, increasing happiness could contribute to lowering health care expenses and, thus, have an impact not only on public health but also on the country's economy $[5,8]$.

The abovementioned factors are mostly evaluated and analyzed among adults. Children and adolescents, however, are much less investigated in this regard, even though their psychoemotional state is often crucial for their overall health in the absence of physical illness or disability. Here, longitudinal studies show that positive well-being (such as positive affect and self-esteem) during adolescence is associated with better perceived general health during young adulthood when controlling for depressive symptoms. Another large-scale cross-sectional study investigated adolescents and found that a low happiness level was strongly associated with sleep problems [9]. In addition, positive well-being is also significantly related to fewer risky health behaviors, such as insufficient physical activity, fast food, binge drinking, smoking, and the use of illegal substances $[10,11]$. Other studies also confirm that higher happiness scores protect adolescents against cigarette smoking [12]. Moreover, higher unhappiness can be observed in schoolchildren who have very poor or non-intact families [11]. Overall, happiness as a positive affect could be the key indicator of adolescent psychoemotional well-being, quality of life, or even future success [13]. These results suggest that a sufficient level of happiness at a young age could be a predictor of health behavior and later health outcomes. Therefore, the assessment of happiness and efforts to increase it should be an important public health concern, as it relates to both the current and future physical and mental health of a population.

Despite a large quantity of research on happiness, there still is a problem regarding its terminology. In both science and practice, the construct of happiness is often used interchangeably with life satisfaction, subjective well-being, quality of life, flourishing, or contentment $[12,14,15]$.

Therefore, when considering happiness, one of the most problematic aspects is measurement. Many different tools are used to evaluate this construct, raising the question of a "gold standard" for the accurate measurement of adolescent happiness.

Recent examples of studies assessing adolescent happiness have used the Subjective Happiness Scale [16,17], the Oxford Happiness Questionnaire [18], the Oxford Happiness Inventory [19], or several variations of a single-item question about the respondents' current degree of happiness [20]. However, some authors refer to certain tools as measures of happiness even though the instruments do not measure happiness as such (e.g., the WHO-5 Well-being Index ([21,22]). In some instances, authors use questions or subscales to measure happiness from larger-scope scales that are normally used to measure another subject, e.g., the Piers-Harris Children's Self-Concept Scale [23] or the Profile of Mood States (POMS) questionnaire [24].

To our knowledge, there are some literature reviews about youth life satisfaction [25] and a systematic review on well-being measurements [26]. However, there is a lack of reviews about the tools used to evaluate adolescent happiness. In this context, the aim of this review is to fill that gap by reviewing the instruments that have been used to assess adolescent happiness over the last 10 years. In addition, we review happiness-related validation studies and the potential need for such validation.

\section{Materials and Methods}

\subsection{Literature Search Strategy}

The systematic review was carried out following the preferred reporting items for systematic reviews and meta-analyses (PRISMA) recommendations for systematic reviews [27]. A systematic literature search was conducted in February 2020 to identify all relevant studies published from 1 January 2010 to 31 December 2019. The search was performed in two 
electronic databases: PubMed and PsycArticles. To identify the studies on happiness, the search keyword "happiness" was combined (using the conjunction AND) with specifications of the age group: "adolescent", "adolescents", "adolescence", "child", "children", "childhood", "schoolchildren", "school-children", "youth", "youngster", "youngsters", "teenager", "teenagers", “teen", “teens", “student", "students", “kid", “kids", "pupil", "pupils", and "juvenile".

\subsection{Selection Criteria}

The eligibility criteria were developed by three reviewers (J.L., G.A.-Z. and K.Š.), who are all co-authors of the present article. The reviewing team consisted of experts in adolescent health and psychology. Reviewers independently applied the pre-defined inclusion and exclusion criteria for the retrieved articles.

\subsubsection{Inclusion Criteria}

The inclusion criteria encompassed scientific papers in all languages that reported the assessment of adolescent happiness and were published in peer-reviewed journals. Only the articles with the full text available were included.

\subsubsection{Exclusion Criteria}

The exclusion criteria were as follows: duplicate search results, studies having no adolescent participants (our target group was 11 to 17 years old), non-empirical studies, review papers (e.g., systematic or another reviews and meta-analyses), qualitative studies, papers not specifying the method for measuring happiness, studies addressing a specific aspect of happiness (such as school-, body-, family-, pregnancy-, or oral-health-related happiness) as opposed to general happiness, and studies where happiness was not selfreported by adolescents (e.g., assessed by their parents or teachers).

\subsection{Study Selection Process and Data Extraction}

First, a literature search was conducted in the scientific databases by combining keywords. Afterwards, we identified and excluded the duplicated articles. After this first selection, the titles and abstracts of the articles found were reviewed. Next, a second exclusion process was made of those studies that did not fulfill the inclusion criteria. The articles obtained after this last selection were evaluated in depth to check for the specific inclusion criteria. Finally, the studies that form part of this review were identified. Each article was reviewed independently by two of the three investigators (J.L., G.A.-Z. and K.Š.) with an almost equal overall number of reviewed papers per investigator. Discrepancies between the reviewers were resolved by discussion and consensus. Using a structured template by all reviewers, the following information was retrieved and summarized: publication's author(s), year, country of study, design of the study, sample (total size and gender ratio), sample type (clinical or non-clinical), response rate, and happiness measurement tool (scale, subscale or question, response options, and internal consistency).

The data were extracted from the original articles. In the case of insufficient data or unclear reporting, the original articles' authors were contacted by email. In total, 18 authors were contacted and 11 of them provided additional information for use in this review.

\subsection{Assessment of the the Methodological Quality of the Studies}

These criteria were developed due to the lack of existing quality assessment checklists for different study designs. According to our knowledge, many checklists were developed for the quality assessment of randomized controlled trials, cohort studies, or case-control studies. However, the tools for observational epidemiological studies in general [28] and cross-sectional studies in particular are not well accepted [29], even though they comprise the largest part of the studies under this systematic review. Our criteria were selected based on previous review studies about methodological quality assessment [30] and already developed tools, such as The Newcastle-Ottawa Scale (NOS) for assessing the quality of 
non-randomized studies in meta-analyses [31], the NIH quality assessment tool [32], and the CASP (Critical Appraisal Skills Programme) [33] checklists.

The quality of the studies included in this systematic review were assessed using 5 criteria with 1 to 3 quality stars, giving scores ranging from a minimum of 5 stars to a maximum 15 stars (Table 1). The quality score was used to indicate the strength of the evidence from the individual studies but was not used to determine their inclusion or exclusion within the review. The methodological quality assessment was performed independently by all three authors (J.L., G.A.-Z. and K.Š.), with each article being reviewed by two researchers. The third researcher was consulted in the case of discrepancies. Since this study did not investigate the effectiveness of interventions, neither a risk of bias evaluation nor a meta-analysis were performed.

Table 1. Description of criteria for the methodological quality of the articles under review.

\begin{tabular}{cccc}
\hline Criterion & 3 Stars & 2 Stars & 1 Star \\
\hline $\begin{array}{c}\text { Representativeness of } \\
\text { sample }\end{array}$ & Yes, representative & $\begin{array}{c}\text { Not defined as representative, but } \\
\text { coming from the general } \\
\text { population }\end{array}$ & $\begin{array}{c}\text { Selective, convenient, and similar } \\
\text { sample or no data }\end{array}$ \\
\hline Response rate & At least $80 \%$ & $50 \%$ to $80 \%$ & Below $50 \%$ or no data \\
\hline Gender balance & $\begin{array}{c}\text { Difference between } \\
\text { genders of less than } 20 \%\end{array}$ & $\begin{array}{c}\text { Difference between genders of } \\
20-50 \%\end{array}$ & $\begin{array}{c}\text { Difference between genders of } \\
\text { more than } 50 \% \text { or no data }\end{array}$ \\
\hline Sample size & At least 1000 & 100 to 1000 & Less than 100 \\
\hline Measurement tool & $\begin{array}{c}\text { Internationally used scale } \\
\text { or subscale of happiness }\end{array}$ & $\begin{array}{c}\text { Single item, including those } \\
\text { drawn from other scales }\end{array}$ & $\begin{array}{c}\text { Unique set of items and } \\
\text { undefined scale }\end{array}$ \\
\hline
\end{tabular}

\section{Results}

\subsection{Study Selection}

In total, the initial search yielded 12,808 records of scientific publications. Once duplicates were removed, 2057 publications were identified. These publications were screened according to the eligibility criteria in the titles, abstracts, and full texts. Figure 1 shows a PRISMA flow chart depicting the articles' identification, screening, eligibility, and the inclusion process.

The titles and abstracts of the publications were analyzed using the inclusion and exclusion criteria, and 1057 articles were excluded. Furthermore, 1000 articles were reviewed and 867 of them were excluded after accessing the full texts, leaving 133 papers in the review. The majority of the articles were excluded due to the age of the sample (age group outside of the 11-17 years range).

\subsection{Characteristics of the Included Studies}

An analysis of the studies by country revealed that adolescent happiness was most frequently investigated in the UK (17 studies of 133), 12 studies were conducted in South Korea, and 11 were conducted in the USA. The majority of the studies were conducted in Europe and Asia (mostly east Asia). Moreover, there were 12 international studies found that covered up to 109 countries. The main characteristics of the included studies are shown in Appendix A (Table A1).

More than half of the articles $(n=88)$ had a sample size above 500 (median $n=1165$ ). Usually, the group of interest was a general population of adolescents $(n=120)$, drawn based on randomization, convenience, or school sampling. Some studies investigated adolescents with clinical conditions $(n=10)$ or compared them with non-clinical subgroups $(n=3)$. The majority of the studies used a cross-sectional design $(n=101)$. More rarely, the studies were longitudinal $(n=23)$ and several studies had experimental or twin designs. Mostly $(n=108)$, the gender distribution was approximately balanced. According to the participants' age, more than one-third of the studies $(n=57)$ analyzed only adolescents 
aged 11-17 years. However, some studies included not only adolescents but children and adults as well, and their findings were not always separated by age group.

$(n=12,586)$

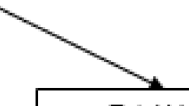

Total identified records $(n=12,808)$

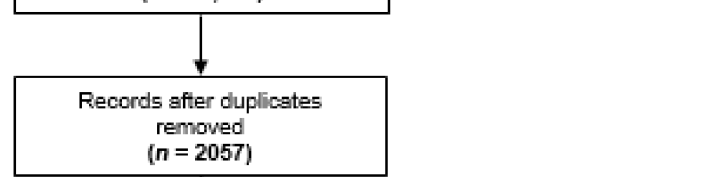
$(n=2057)$
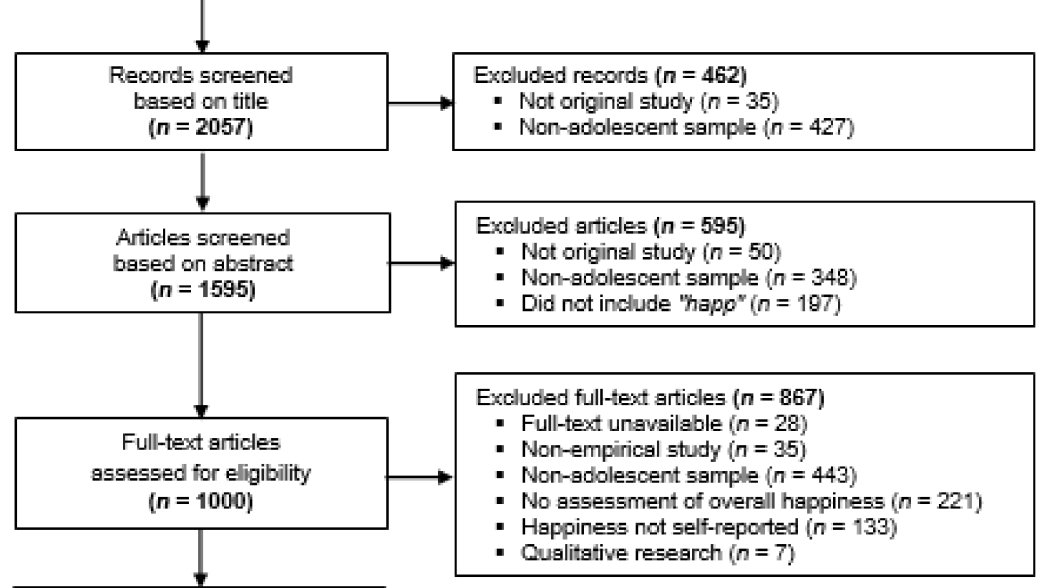

Articles included

in the systematic review $(n=133)$

Figure 1. PRISMA flow chart of the systematic literature review.

\subsection{Study Quality Assessment}

All included studies had a generally moderate to high quality, ranging from 7 to 15 , with median of 11 and a visually normal distribution (Table 2). The highest medians (3 points) were observed for the criteria of gender balance and sample size. Lower medians ( 2 points) were observed for representativeness and measurement, while the lowest median was observed for the response rate (1 point). The study quality assessments for each criterion of all included studies is shown in Appendix B (Table A2).

Table 2. Description of the criteria for the methodological quality of the articles under review.

\begin{tabular}{ccc}
\hline Total Quality Score & Number of Studies & Reference \\
\hline 7 & 2 & {$[34,35]$} \\
\hline 8 & 10 & {$[36-45]$} \\
\hline 9 & 23 & {$[23,46-67]$} \\
\hline 10 & 23 & {$[24,68-89]$} \\
\hline 11 & 20 & {$[4,90-108]$} \\
\hline 12 & 31 & {$[22,109-138]$} \\
\hline 13 & 12 & {$[11,139-149]$} \\
\hline 14 & 9 & {$[12,150-157]$} \\
\hline 15 & 3 & {$[158-160]$}
\end{tabular}




\subsection{Happiness Assessment Tools}

\subsubsection{Single-Item Happiness Measures}

Almost half of the studies under review (64 of 133) evaluated subjective happiness using single-item measures. The questions addressing the perception of happiness were mainly concerned with how the participants perceived the present moment or current period $(n=20)$. Some asked about life in general $(n=15)$ and many studies did not specify the approach $(n=25)$ (Figure 2$)$. Several studies employed a specific time to describe the perception of happiness, such as the last week [125], last two weeks [157], or last month [146] (Appendix C, Table A3).

Perception of life vs moment

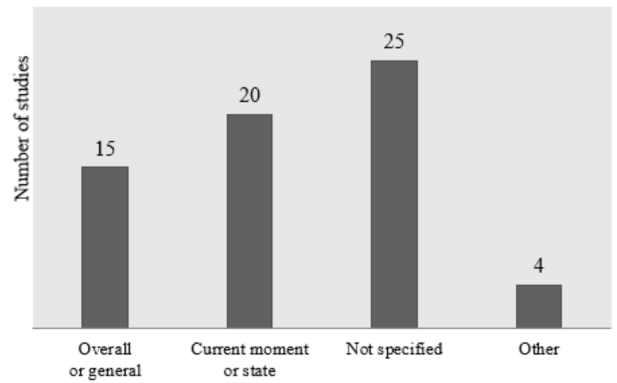

Response types

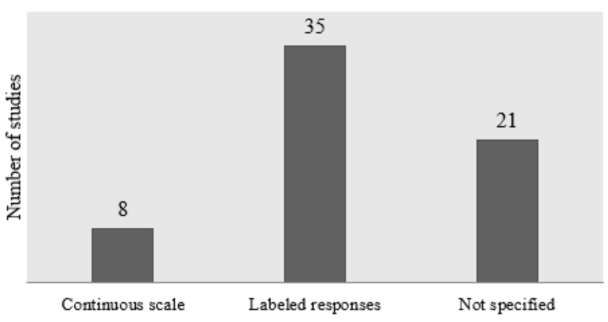

Emphasis on self or life

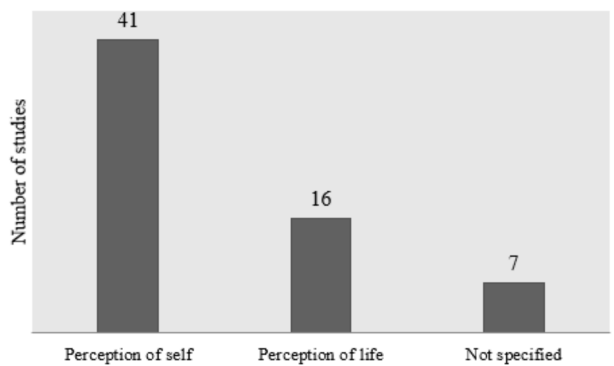

Response ranges

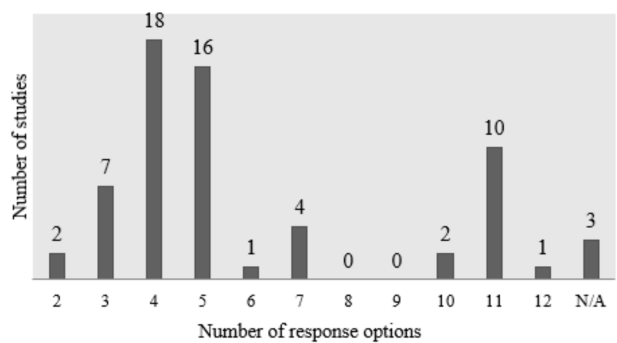

Figure 2. The main features of the single-item measures.

It should also be noted that the majority of the studies with single-item measures $(n=41)$ formulated the item more towards one's feelings or perceptions of the self as happy, e.g., "In general, are you happy lately?" [101] or "How would you say you feel these days?" [96], while others $(n=16)$ focused on the perception of a happy life rather than self, such as "I feel happy about life" [76] or "In general, how do you feel about your life at present?" [156].

Studies with single-item measures used various ranges of responses options to the question. More frequently the studies had an odd number of responses than an even number (37 versus 24). When comparing the range of response options, there was a clear preference for $4(n=18)$ or 5 response options $(n=16)$ rather than any other range.

In total, 56 of 64 articles on studies with single-item measures of happiness explicitly described the response options, which were mostly framed as numerical scales with labeled captions to go along with the numbers. Overall, 35 studies defined labels with every ordinal response option (e.g., "very happy", "happy", "average", "unhappy", and "very unhappy"), with only two of the studies using a dichotomous measure [74,76]. Several studies $(n=7)$ used continuous scales with only the lowest and highest values labeled, and this was usually seen with response options in the 10- or 11-point range. There was an overall trend that labeled responses were preferred for shorter ranges and longer ones were not labeled.

\subsubsection{Multiple-Item Happiness Scales}

The summarized results of the happiness questionnaires used for adolescents are presented in Table 3. The most commonly used scale was the 4-item Subjective Happiness 
Scale (SHS) [3], which was used in 24 studies. All other scales were used much more rarely, the most common of them being the Oxford Happiness Questionnaire (OHQ) [161] with longer 29-item $(n=7)$ and shorter 8-item $(n=5)$ versions. Overall, it was observed that validated questionnaires were chosen more frequently than unique scales. Newer questionnaires tended to be shorter, including less than 10 items. Detailed information on the studies, by scale and their internal consistency, is presented in Appendix D (Table A4).

Table 3. Happiness scales and their structural information.

\begin{tabular}{ccccc}
\hline Scale & Scale Author(s), Year & Number of Items & Dimension(s) & Number of Studies \\
\hline $\begin{array}{c}\text { Subjective Happiness } \\
\text { Scale (SHS) }\end{array}$ & $\begin{array}{c}\text { Lyubomirsky and } \\
\text { Lepper 1999 [3] }\end{array}$ & 4 & Unidimensional & 24 \\
\hline $\begin{array}{c}\text { Oxford Happiness } \\
\text { Questionnaire (OHQ) }\end{array}$ & $\begin{array}{c}\text { Hills and Argyle, 2002 } \\
{[161]}\end{array}$ & 29 & Unidimensional & 7 \\
\hline $\begin{array}{c}\text { Oxford Happiness } \\
\text { Questionnaire-Short } \\
\text { Form (OHQ-sf) }\end{array}$ & $\begin{array}{c}\text { Hills and Argyle, 2002 } \\
{[161]}\end{array}$ & 8 & Unidimensional & 5 \\
\hline
\end{tabular}

(1) satisfaction with life,

Oxford Happiness

Inventory (OHI)

Argyle et al., 1989 [162]
29

\begin{tabular}{cc}
\hline $\begin{array}{c}\text { [scale title undefined in } \\
\text { the article] }\end{array}$ & $\begin{array}{c}\text { Chan and Koo, } 2011 \\
\text { [163] }\end{array}$ \\
& \\
Pemberton Happiness \\
Index
\end{tabular}$\quad \begin{gathered}\text { Hervás and Vázquez, } \\
2013 \text { [22] }\end{gathered}$

(2) mastery and self-fulfillment,

(3) social cheerfulness,

(4) vigor, and

(5) social interest

Unidimensional

Unidimensional

3

(1) remembered well-being (general, hedonic, eudaimonic, and social well-being),

(2) experienced well-being (i.e., positive and negative emotional events that possibly happened the day before)

\begin{tabular}{|c|c|c|c|c|}
\hline $\begin{array}{l}\text { Humboldt Happiness } \\
\text { Scale-Adolescent } \\
\text { Version (HHSAV) }\end{array}$ & Reynolds, 2005 [164] & 28 & Unidimensional & 1 \\
\hline $\begin{array}{l}\text { Happiness Measures } \\
(\mathrm{HM})\end{array}$ & Fordyce, 1988 [165] & 2 & $\begin{array}{c}\text { Unidimensional (but the study } \\
\text { in this review was used as } \\
\text { multidimensional) }\end{array}$ & 1 \\
\hline $\begin{array}{l}\text { Gross National } \\
\text { Happiness Abridged } \\
\text { Survey (GNHAS) } \\
\text { questionnaire }\end{array}$ & $\begin{array}{c}\text { Pennock and Ura, } 2012 \\
\text { [166] }\end{array}$ & 48 & $\begin{array}{c}\text { psychological well-being, } \\
\text { health, } \\
\text { education, } \\
\text { culture, } \\
\text { time use, } \\
\text { governance, } \\
\text { community vitality, } \\
\text { ecological diversity resilience, } \\
\text { and } \\
\text { living standards }\end{array}$ & 1 \\
\hline $\begin{array}{l}\text { WHO-5 Well-being } \\
\text { Index }\end{array}$ & $\begin{array}{c}\text { World Health } \\
\text { Organization, } 1998 \text { [21] }\end{array}$ & 5 & Unidimensional & 1 \\
\hline $\begin{array}{l}\text { [scale title undefined in } \\
\text { article] }\end{array}$ & Quy, 2019 [64] & 9 & Unidimensional & 1 \\
\hline $\begin{array}{l}\text { [scale title undefined in } \\
\text { article] }\end{array}$ & $\begin{array}{c}\text { Schacter and Margolin, } \\
2019 \text { [65] }\end{array}$ & 3 & Unidimensional & 1 \\
\hline
\end{tabular}




\subsubsection{Happiness as a Part of Other Scales}

Some studies measured happiness using some subscales from the tools that measure concepts larger than happiness (Table 4 ). The most commonly used scales of this kind were the Piers-Harris Children's Self-Concept Scale $(n=5)$ and the Profile of Mood States (POMS) $(n=4)$. Most frequently, the happiness items (subscales) comprised the minor part in such scales. There were some inconsistencies with subscale use, where some studies chose to use particular sets of items for happiness, even though such items were measuring not only happiness but also feeling joyful, calm, cheerful, or satisfied. Detailed information on the studies, by subscale and their internal consistency, is presented in Appendix E (Table A5).

Table 4. Happiness subscales from the validated scales.

\begin{tabular}{|c|c|c|c|c|c|}
\hline Scale & Version & $\begin{array}{l}\text { Author(s), } \\
\text { Year }\end{array}$ & Subscales & $\begin{array}{l}\text { Number of Happiness } \\
\text { Items of Total Items }\end{array}$ & $\begin{array}{l}\text { Number of } \\
\text { Studies }\end{array}$ \\
\hline \multirow{2}{*}{$\begin{array}{l}\text { Piers-Harris } \\
\text { Children's } \\
\text { Self-Concept } \\
\text { Scale } \\
\text { (PHC-SCS) }\end{array}$} & $\begin{array}{l}\text { Piers-Harris } \\
\text { Children's } \\
\text { Self-Concept } \\
\text { Scale }\end{array}$ & $\begin{array}{l}\text { Piers and } \\
\text { Harris, } \\
1963[167]\end{array}$ & $\begin{array}{l}\text { Behavior, Intellectual and } \\
\text { School Status, Physical } \\
\text { Appearance and Attributes, } \\
\text { Anxiety, Popularity, and } \\
\text { Happiness and Satisfaction }\end{array}$ & 10 of 80 & 4 \\
\hline & $\begin{array}{l}\text { Piers-Harris } 2 \\
\text { Children's } \\
\text { Self-Concept } \\
\text { Scale }\end{array}$ & $\begin{array}{l}\text { Piers and } \\
\text { Herzberg, } \\
2002[168]\end{array}$ & $\begin{array}{l}\text { Behavioral Adjustment, } \\
\text { Intellectual and School Status, } \\
\text { Physical Appearance and } \\
\text { Attributes, Freedom from } \\
\text { Anxiety, Popularity, and } \\
\text { Happiness and Satisfaction }\end{array}$ & 10 of 60 & 1 \\
\hline \multirow[t]{2}{*}{$\begin{array}{l}\text { Profile of Mood } \\
\text { States (POMS) }\end{array}$} & $\begin{array}{l}\text { Profile of Mood } \\
\text { States } \\
\text { questionnaire }\end{array}$ & $\begin{array}{l}\text { McNair } \\
\text { et al., 1971 } \\
{[169]}\end{array}$ & $\begin{array}{c}\text { Anger, Confusion, Depression, } \\
\text { Fatigue, Tension, and Vigor. } \\
\text { The modifications (by Kiang } \\
\text { and Buchanan in } 2013 \text { and } \\
\text { Mercado et al. in } 2019 \text { include } \\
\text { Happiness (joyful, happy, and } \\
\text { calm). }\end{array}$ & 3 of 65 & $3 *$ \\
\hline & $\begin{array}{l}\text { Adolescent } \\
\text { version } \\
\text { (POMS-A) }\end{array}$ & $\begin{array}{l}\text { Terry et al., } \\
1999 \text { [170] }\end{array}$ & $\begin{array}{l}\text { Anger, Confusion, Depression, } \\
\text { Fatigue, Tension, and Vigor }\end{array}$ & 2 of 24 & $1 * *$ \\
\hline \multicolumn{2}{|c|}{$\begin{array}{c}\text { EPOCH measure of Adolescent } \\
\text { Well-Being }\end{array}$} & $\begin{array}{l}\text { Kern et al., } \\
2016[57]\end{array}$ & $\begin{array}{c}\text { EPOCH Measure of } \\
\text { Adolescent Well-Being, which } \\
\text { assesses five positive } \\
\text { psychological characteristics } \\
\text { (Engagement, Perseverance, } \\
\text { Optimism, Connectedness, } \\
\text { and Happiness) }\end{array}$ & 4 of 20 & 4 \\
\hline \multicolumn{2}{|c|}{$\begin{array}{c}\text { Daily Mood Scale, an Internet } \\
\text { version of the Electronic Mood } \\
\text { Device }\end{array}$} & $\begin{array}{c}\text { Hoeksma } \\
\text { et al., } 2000 \\
{[171]}\end{array}$ & $\begin{array}{c}\text { Happiness (glad, happy, and } \\
\text { cheerful), anger (angry, cross, } \\
\text { and short-tempered), anxiety } \\
\text { (afraid, anxious, and worried), } \\
\text { and sadness (sad, down, and } \\
\text { dreary) }\end{array}$ & 3 of 12 & 3 \\
\hline $\begin{array}{l}\text { Positive and } \\
\text { Negative } \\
\text { Affect Scale }\end{array}$ & $\begin{array}{l}\text { For Children } \\
\text { (PANAS-C) }\end{array}$ & $\begin{array}{l}\text { Laurent } \\
\text { et al., } 1999 \\
{[172]}\end{array}$ & $\begin{array}{l}1 \text { item on 'happy' as a part of } \\
\text { the Positive Affect subscale }\end{array}$ & 1 of 30 & $2 * * *$ \\
\hline
\end{tabular}




\subsection{Validation of Happiness Measures}

Among the analyzed 133 articles, 18 reported some validation processes related to happiness. However, in the majority of cases $(n=14)$, happiness was not the central phenomenon of interest, it was a subject for the validity of other constructs. It should be noted that virtually all validation procedures included either convergent or concurrent validity and very rarely included any other type of validity (Table 5). None of the studies addressed discriminant or predictive validity.

Table 5. Happiness-related validation studies.

\begin{tabular}{|c|c|c|c|c|c|}
\hline Study & Center & Happiness Scale & $\begin{array}{l}\text { Construct Validity: } \\
\text { Convergent }\end{array}$ & $\begin{array}{l}\text { Criterion Validity: } \\
\text { Concurrent }\end{array}$ & Content Validity \\
\hline $\begin{array}{l}\text { Abdel-Khalek, } \\
2011[46]\end{array}$ & Happiness & $\begin{array}{c}\text { Oxford } \\
\text { Happiness } \\
\text { Inventory }(\mathrm{OHI})\end{array}$ & $\begin{array}{l}\text { Happiness correlates with } \\
\text { other positive affect measures } \\
\text { (love of life scale, life } \\
\text { satisfaction scale, the mental } \\
\text { health item, and the life } \\
\text { satisfaction item). }\end{array}$ & & $\begin{array}{l}\text { Correlation } \\
\text { between two } \\
\text { happiness } \\
\text { measures }\end{array}$ \\
\hline $\begin{array}{c}\text { Ali et al., } 2012 \\
\text { [90] }\end{array}$ & Happiness & Single item & $\begin{array}{l}\text { Happiness correlates with } \\
\text { being calm and peaceful (rho } \\
=0.43 \text { ), lots of energy (rho = } \\
0.37) \text {, full of life (rho }=0.48 \text { ), } \\
\text { the } 4 \text {-item composite score } \\
\text { (rho }=0.70) \text {, and with IQ. }\end{array}$ & & \\
\hline $\begin{array}{l}\text { Lung and Shu, } \\
2020[159]\end{array}$ & Happiness & $\begin{array}{c}\text { Oxford } \\
\text { Happiness } \\
\text { Questionnaire } \\
\text { (OHQ) }\end{array}$ & $\begin{array}{l}\text { Happiness associates with } \\
\text { psychological well-being and } \\
\text { social adaptation. }\end{array}$ & & \\
\hline $\begin{array}{c}\text { Hervás and } \\
\text { Vázquez, } 2013 \\
\text { [22] }\end{array}$ & Well-being & $\begin{array}{l}\text { Pemberton } \\
\text { Happiness Index }\end{array}$ & $\begin{array}{l}\text { Happiness associates with } \\
\text { different aspects of well-being } \\
\text { and life satisfaction. }\end{array}$ & $\begin{array}{c}\text { Happiness associates } \\
\text { with sleep quality } \\
\text { and perceived } \\
\text { health. }\end{array}$ & \\
\hline $\begin{array}{l}\text { Brasseur et al., } \\
\quad 2013 \text { [49] }\end{array}$ & $\begin{array}{l}\text { Emotional } \\
\text { competence }\end{array}$ & $\begin{array}{c}\text { Subjective } \\
\text { Happiness Scale } \\
\text { (SHS) }\end{array}$ & & $\begin{array}{l}\text { Happiness correlates } \\
\text { with overall } \\
\text { emotional } \\
\text { competence } \\
(\mathrm{r}=0.40) .\end{array}$ & \\
\hline $\begin{array}{l}\text { Chen et al., } \\
2012 \text { [37] }\end{array}$ & $\begin{array}{l}\text { Emotional } \\
\text { expression } \\
\text { and } \\
\text { Gratitude }\end{array}$ & Single item & $\begin{array}{l}\text { Happiness correlates with } \\
\text { gratitude ( } \mathrm{r} \text { from } 0.31 \text { to } 0.46) \\
\text { and ambivalence over } \\
\text { emotional expression ( } \mathrm{r} \text { from } \\
\quad-0.13 \text { to }-0.18) \text {. }\end{array}$ & & \\
\hline $\begin{array}{l}\text { Cooper et al., } \\
2011[113]\end{array}$ & $\begin{array}{l}\text { Neurotic } \\
\text { symptoms }\end{array}$ & Single item & $\begin{array}{l}\text { Happiness associates with } \\
\text { neuroticism. }\end{array}$ & & \\
\hline $\begin{array}{l}\text { de Bruin et al., } \\
2011 \text { [139] }\end{array}$ & Mindfulness & $\begin{array}{c}\text { Subjective } \\
\text { Happiness Scale } \\
\text { (SHS) }\end{array}$ & $\begin{array}{l}\text { Happiness correlates with } \\
\text { mindful attention awareness } \\
\qquad(\mathrm{r}=0.33)\end{array}$ & & \\
\hline $\begin{array}{l}\text { Disabato et al., } \\
2015 \text { [53] }\end{array}$ & $\begin{array}{l}\text { Hedonic and } \\
\text { eudaimonic } \\
\text { well-being }\end{array}$ & $\begin{array}{c}\text { Subjective } \\
\text { Happiness Scale } \\
\text { (SHS) }\end{array}$ & $\begin{array}{l}\text { Happiness correlates with } \\
\text { hedonic and eudaimonic } \\
\text { well-being. }\end{array}$ & & \\
\hline $\begin{array}{l}\text { Lardon et al., } \\
2016[100]\end{array}$ & Wellness & Single item & $\begin{array}{l}\text { Happiness associates with } \\
\text { different well-being measures. }\end{array}$ & & \\
\hline $\begin{array}{l}\text { Mahfoud et al., } \\
\text { 2011 [59] }\end{array}$ & $\begin{array}{l}\text { Mental } \\
\text { health }\end{array}$ & Single item & $\begin{array}{l}\text { Happiness associates with } \\
\text { better mental health. }\end{array}$ & & \\
\hline
\end{tabular}


Table 5. Cont.

\begin{tabular}{|c|c|c|c|c|c|}
\hline Study & Center & Happiness Scale & $\begin{array}{l}\text { Construct Validity: } \\
\text { Convergent }\end{array}$ & $\begin{array}{l}\text { Criterion Validity: } \\
\text { Concurrent }\end{array}$ & Content Validity \\
\hline $\begin{array}{l}\text { Meleddu et al., } \\
2012[124]\end{array}$ & $\begin{array}{c}\text { Personality } \\
\text { inventory } \\
\text { and } \\
\text { Self-esteem }\end{array}$ & $\begin{array}{c}\text { Oxford } \\
\text { Happiness } \\
\text { Inventory }(\mathrm{OHI})\end{array}$ & & $\begin{array}{l}\text { Happiness correlates } \\
\text { with extraversion } \\
(\mathrm{r}=0.48), \text { neuroticism } \\
(\mathrm{r}=-0.53), \text { and } \\
\text { self-esteem }(\mathrm{r}=0.63) \\
\text { but not psychoticism } \\
\quad(\mathrm{r}=-0.04) .\end{array}$ & \\
\hline $\begin{array}{l}\text { Fat et al., } 2016 \\
{[141]}\end{array}$ & $\begin{array}{c}\text { Mental } \\
\text { well-being }\end{array}$ & Single item & & $\begin{array}{l}\text { Happiness correlates } \\
\text { with well-being } \\
(\text { rho }=0.53)\end{array}$ & \\
\hline $\begin{array}{l}\text { Quy et al., } 2019 \\
{[64]}\end{array}$ & $\begin{array}{l}\text { Coping } \\
\text { response }\end{array}$ & 9 selected items & & $\begin{array}{l}\text { Happiness associates } \\
\text { with coping ( } \mathrm{d} \text { of } \\
\text { separate items } 0.2 \text { to } \\
1.0)\end{array}$ & \\
\hline $\begin{array}{l}\text { Saarikallio } \\
\text { et al., } 2016[43]\end{array}$ & $\begin{array}{c}\text { Music } \\
\text { perception }\end{array}$ & Single item & & $\begin{array}{l}\text { Happiness correlates } \\
\text { with the perception of } \\
\text { healthy music } \\
(\mathrm{r}=0.21) \text { and } \\
\text { unhealthy music } \\
(\mathrm{r}=-0.38) .\end{array}$ & \\
\hline $\begin{array}{l}\text { Salavera et al., } \\
\quad 2017 \text { [84] }\end{array}$ & $\begin{array}{c}\text { Mind- } \\
\text { wandering }\end{array}$ & $\begin{array}{c}\text { Subjective } \\
\text { Happiness Scale } \\
\text { (SHS) }\end{array}$ & $\begin{array}{l}\text { Happiness correlates with } \\
\text { mind-wandering }(\mathrm{r}=-0.30) \text {. }\end{array}$ & & \\
\hline $\begin{array}{c}\text { Yu et al., } 2011 \\
{[135]}\end{array}$ & Depression & Single item & $\begin{array}{c}\text { Happiness correlates with } \\
\text { depressiveness (rho }=-0.32 \text { ). }\end{array}$ & & \\
\hline $\begin{array}{c}\text { Yu et al., } 2012 \\
{[136]}\end{array}$ & Depression & Single item & $\begin{array}{l}\text { Happiness correlates with } \\
\text { depressiveness }(\mathrm{r}=-0.41)\end{array}$ & & \\
\hline
\end{tabular}

The specifically validated happiness tools were the Oxford Happiness Inventory [46], the Oxford Happiness Questionnaire [159], the Pemberton Happiness Index [22], and a single-item measure [90]. In these cases, mainly convergent validation was assessed, associating happiness with other psychological well-being phenomena, such as life satisfaction, love of life, or positive affect conditions (e. g. calm and peaceful). Such correlations were mainly medium-sized. Studies with comparisons of different happiness measures were very scarce. One study showed that the Oxford Happiness Inventory correlated with a single-item happiness measure (range 0 to 10) at $r=0.57$ [46]. Another study revealed that the Pemberton Happiness Index has incremental validity compared to the Subjective Happiness Scale ( $\mathrm{r}$ varied from 0.69 to 0.83 ), though none of the items of the former directly addressed happiness as such [22].

All other studies that conducted validity calculations related to happiness were mainly focused on the validity of other phenomena of interest, such as well-being [53], emotional competences [37,49], mental health [59,141], personality [124], and other concepts. In contrast to the happiness-centered validation studies, here, concurrent validities were also calculated, apart from convergent. Happiness was related to other measures at small or medium correlation levels. For instance, it was related to lower neuroticism $[113,124]$, higher mindfulness [139], less depression [135,136], and a better coping response [64]. It can also be noted that one study evaluated incremental validity [22].

Altogether it can be seen that the validation studies in the recent research on adolescent happiness are quite limited, mainly addressing other constructs associated with positive affect. There is a lack of studies with predictive validity and test-retest reliability, as well as comparisons of the different happiness tools. 


\section{Discussion}

Happiness, as a phenomenon, has been a much-debated topic, investigated from the perspectives of different scientific disciplines. The current review focused on the psychological perspective. Presently, subjective well-being is once again a topic of interest to many researchers in psychology, and as a consequence, there is a growing body of research on happiness as its component.

Subjective well-being is a complex construct that refers to optimal psychological functioning and experience. It can be categorized into hedonic (the attainment of pleasure and avoidance of suffering), eudaimonic (meaning and purpose in life) [173], and evaluative (evaluations of how satisfied people are with their lives) [174] aspects. Happiness is considered as a part of the hedonic aspect, sometimes referred to as affective well-being [6].

This theoretical perspective makes it clearer why some researchers refer to happiness when, in fact, they measure life satisfaction, which is a construct that represents evaluative rather than affective well-being. The current systematic review also revealed this ambiguity in terminology of happiness. We found several studies in which the authors claimed they had measured and reported happiness while, in fact, they had assessed another, usually larger, aspect of subjective well-being [22,46].

The current analysis included a detailed review of the instruments that assessed happiness to see how this construct was operationalized across studies. While measuring happiness among adolescents, the hedonic perspective was predominant. Items in scales usually approached the participants' current sense or perception of happiness. There was some variation as to the momentary or general sense of happiness, the latter including a time definition (such as two weeks) or simply the words "usually", "overall" or "in general". Most single-item measurements focused on a person's feelings and asked a fairly direct question about their sense of happiness, e.g., "In general, are you happy lately?" [101]. This method gives researchers a clear answer about one's happiness through the face validity.

Meanwhile, when analyzing multiple-item happiness scales, not many direct questions about happiness were observed. For example, the Oxford Happiness Questionnaire [161] contains one direct statement (out of 29 items) related to happiness: "I am very happy". Another example is the Happiness Measures [165], which assesses feelings of happiness related to various life domains: the house or apartment, the people one lives with, the people in one's family, friends, etc. (16 aspects in total). In this way, many various aspects of life are evaluated by asking whether the child feels happy about them. Shorter happiness scales, such as the Subjective Happiness Scale [3], are more oriented to the person and their personal feelings. It gives a shorter and clearer answer but does not assess separate aspects of happiness. Shorter scales result in a lower cognitive load for study participants, which is especially convenient when the target group is young. However, when happiness is a central phenomenon in a study, a validated happiness scale (possibly with subscales) seems to be a more suitable choice, given that psychometric characteristics are appropriate for the selected age group.

The overview of the tools also showed a clear emphasis on happiness as an affective aspect of well-being. Consequently, validity studies addressing happiness were also mainly targeted towards associations with other aspects of subjective well-being, especially with affective states and perceptions. Such affective constructs included depressiveness, neuroticism, emotional expressions, self-esteem, mindfulness, etc. Some validation studies also correlated happiness to cognitive or evaluative aspects of well-being, such as life satisfaction or perceived health [22], and, very rarely, to eudaimonic measures [53]. However, the eudaimonic aspect of well-being is more complicated to measure, especially among younger people, because it requires more extensive cognitive processing [6]. After all, the core of eudaimonic well-being, the meaning or purpose of life, is a presumably less relevant topic in children and adolescents than in adults.

In general, this review showed that in the last decade there was no abundance of validation studies on happiness. The ones we included in our review were mainly designated to validate other constructs, with happiness chosen as a non-central indicator. Specifically, 
the validated measures were the Oxford Happiness Inventory [46], the Oxford Happiness Questionnaire [159], and one single-item measure [90]. The majority of the scales being used in recent research were developed several decades ago. Consequently, it could be worth revisiting the validation in current adolescent samples. It should also be noted that none of the studies measured test-retest reliability to check how consistent the responses on happiness were over time.

The majority of studies using a single item for happiness suggest a continuum with four or five response options. This raises the question of the middle-point: an even number of choices (no middle-point) might force a person to report feeling either happy or unhappy, while an odd number with a middle point allows a responder to choose a doubting or indifferent state or opinion, which does not present the pressure to be happy, even though there may be some cultural preferences [175]. When including an even or odd number of responses, it is also worth considering the similarity with other items in the survey. It is likely better to follow the consistency of other items to decrease cognitive load.

\subsection{Strengths and Limitations}

To the authors' knowledge, this paper represents the most comprehensive attempt to review the measurements that have been used to assess adolescent happiness. This systematic review includes the most recent articles published over the last decade (2010-2019). Moreover, it highlights the trends on which tools are used to assess adolescent happiness, as well as categorizes the measurements by their structure, frequency of use, and scale characteristics. This analysis revealed a lack of validation studies on happiness, which shows the need for such studies, given that many scales are relatively old and, therefore, may be questionable for contemporary adolescents.

However, this review also has some limitations. First, the literature search was performed in two databases. Only articles with an English summary were included in the search, which may have limited the results. However, a lot of duplicates were noticed and removed in the process, which lets the authors assume that not much additional information was lost. Nonetheless, the selected search databases, PubMed and PsycArticles, cover the fields of psychology and biomedicine and are widely used. We suggest that the articles published in journals outside of scope of those databases follow a general trend of scales' use or otherwise choose local variations of happiness measurements that have low potential for international applicability. Moreover, this analysis omitted studies that evaluated an induced sense of happiness, e.g., happiness provoked during an experiment with certain stimuli. This exclusion criterion was chosen because our object was not an aroused, induced, or somehow provoked perception but rather a stable and overall sense of happiness as a state. There were also some studies, mainly experimental studies on emotions, that addressed happiness not as a specific phenomenon but rather as one of the emotional states. For example, children were asked to assess the drawings of facial expressions and then indicate if they felt sad, angry, happy, or scared [176]. Because such studies do not approach happiness per se but happiness as an aroused state within an emotional continuum, such studies were not included in this systematic review. Finally, among the studies included in this systematic review, there were also several covering broader age groups that included adults or children in addition to adolescents. It follows that the results of some studies may not be fully specific to our target group (adolescents).

Given that our review has covered the period from 2010 to 2019, we conducted an extra short overview of the articles from the most recent studies of 2020 and 2021. The vast majority of the studies used the previously administered questionnaires and scales of happiness. Several studies used validated language versions of EPOCH (Swedish [177]), or SHS (Brazilian [178]. In addition, one new scale, HERO, was developed [179] that assesses not only happiness but also enthusiasm, resilience, and optimism and is, thus, a general positive affect or well-being scale rather than a happiness measure per se. Other studies either used previously established scales or approached happiness as a validation tool for another constructs. 


\subsection{Suggestions for the Choice of Happiness Measurements}

- We suggest using specific tools (items or scales) for happiness instead of broader approaches. Moreover, when selecting the scale for measuring happiness, it is important to choose the one that specifically measures happiness and not just related constructs of well-being.

- The most common tools to measure happiness in adolescents are single-item measures, the Subjective Happiness Scale, and the Oxford Happiness Questionnaire. For the choice, it is important to decide on the length of the questionnaire. In studies where happiness is one of the constructs among others, a better option would be to choose either a single item or a short scale (e.g., the 4-item SHS) because other happiness scales are relatively long, which may be an obstacle for younger samples.

- If a single-item measure is chosen, the critical task is to decide on its range (four or five response options are used most commonly) and whether to use a continuous (visual-analogue) scale or labeled response options. In addition to that, when choosing a single item, it is relevant to keep in mind odd or even number responses. In the case of an odd number, there is an opportunity for the responder to choose the middle-point option without feeling forced to report being happy or unhappy.

- To increase the comparability of different studies' findings, it is relevant to have approximately similar measurement tools addressing more or less the same construct. In the case of single-item happiness measures, it can be seen that some studies ask about the general, overall sense of happiness, while others specify the timing or situations.

\section{Conclusions}

In conclusion, this review provides a summary of the commonly used measures for assessing adolescent happiness. The research on happiness uses a variety of methods and instruments. About half of the studies included in the review assessed happiness using a single item, mostly employing statements that explicitly refer to being happy or the sense of happiness. This seems to be the gold standard in happiness research with single-item measures. Some studies refer to happiness even when measuring broader concepts related to subjective well-being. Other studies use more detailed approaches, providing data based on scales with multiple items. In contrast to the single items, however, such scales are much more diverse in covering not only the exact sense of happiness but also assessing different aspects of well-being and positive affect.

Author Contributions: Conceptualization, methodology, and writing and editing the manuscript were completed by all authors. All authors have read and agreed to the published version of the manuscript.

Funding: This research received no external funding.

Institutional Review Board Statement: Not required, as the current study is a systematic review of only published articles.

Informed Consent Statement: Not required, as the current study is a systematic review of only published articles and does not include human or animal participants.

Data Availability Statement: Not applicable.

Conflicts of Interest: The authors declare no conflict of interest.

\section{Appendix A}

Table A1. The main characteristics of each study included in the systematic review.

\begin{tabular}{lllllll}
\hline \multicolumn{1}{c}{ Study } & Country & Study Design & n & Female \% & Sample & $\begin{array}{c}\text { Happiness } \\
\text { Measurement }\end{array}$ \\
\hline $\begin{array}{l}\text { Bartels et al., 2010 } \\
{[109]}\end{array}$ & Netherlands & Twin study & 12,279 & 56 & General & $\begin{array}{l}\text { Subjective Happiness } \\
\text { Scale (SHS) }\end{array}$ \\
\hline
\end{tabular}


Table A1. Cont.

\begin{tabular}{|c|c|c|c|c|c|c|}
\hline Study & Country & Study Design & n & Female \% & Sample & $\begin{array}{c}\text { Happiness } \\
\text { Measurement }\end{array}$ \\
\hline $\begin{array}{l}\text { Gaspar de Matos } \\
\text { et al., } 2010 \text { [117] }\end{array}$ & Portugal & Cross-sectional & 6131 & 51 & General & Single item \\
\hline $\begin{array}{l}\text { González- } \\
\text { Quiñones and } \\
\text { Restrepo- } \\
\text { Chavarriaga, } \\
2010 \text { [118] }\end{array}$ & Colombia & Cross-sectional & 2222 & 49 & General & Single item \\
\hline $\begin{array}{l}\text { Phongsavan et al., } \\
2010 \text { [128] }\end{array}$ & $\begin{array}{l}\text { International } \\
\text { study } \\
\text { ( } 3 \text { countries })\end{array}$ & Cross-sectional & 5000 & 51 & General & Single item \\
\hline $\begin{array}{l}\text { Abdel-Khalek, } \\
2011[46]\end{array}$ & Egypt & Cross-sectional & 224 & 55 & General & Single item \\
\hline $\begin{array}{l}\text { Bolat et al., } 2011 \\
\text { [23] }\end{array}$ & Turkey & Cross-sectional & 80 & 42 & Mixed & $\begin{array}{l}\text { Piers-Harris Children's } \\
\text { Self-Concept Scale } \\
\text { (PHC-SCS), Happiness } \\
\text { subscale }\end{array}$ \\
\hline $\begin{array}{l}\text { Burrow and Hill, } \\
2011 \text { [70] }\end{array}$ & USA & Cross-sectional & 100 & 51 & General & $\begin{array}{l}\text { Subjective Happiness } \\
\text { Scale (SHS) }\end{array}$ \\
\hline $\begin{array}{l}\text { Cooper et al., } \\
2011 \text { [113] }\end{array}$ & England & Cross-sectional & 7399 & 57 & General & Single item \\
\hline $\begin{array}{l}\text { de Bruin et al., } \\
2011 \text { [139] }\end{array}$ & Netherlands & Cross-sectional & 781 & 49 & General & $\begin{array}{l}\text { Subjective Happiness } \\
\text { Scale (SHS) }\end{array}$ \\
\hline $\begin{array}{l}\text { Fonseca and } \\
\text { Matos, } 2011 \text { [116] }\end{array}$ & Portugal & Cross-sectional & 4817 & 50 & General & Single item \\
\hline $\begin{array}{l}\text { Yu et al., } 2011 \\
{[136]}\end{array}$ & Hong Kong & Cross-sectional & 6028 & 54 & General & Single item \\
\hline $\begin{array}{l}\text { Yu et al., } 2012 \\
\text { [135] }\end{array}$ & Hong Kong & Cross-sectional & 6028 & 54 & General & Single item \\
\hline $\begin{array}{l}\text { Lázaro et al., } 2011 \\
\text { [38] }\end{array}$ & Spain & Longitudinal & 160 & 94 & Clinical & $\begin{array}{l}\text { Piers-Harris Children's } \\
\text { Self-Concept Scale } \\
\text { (PHC-SCS), Happiness } \\
\text { subscale }\end{array}$ \\
\hline Levin, 2011 [153] & Scotland & Cross-sectional & 5958 & 52 & General & Single item \\
\hline $\begin{array}{l}\text { Mahfoud et al., } \\
2011 \text { [59] }\end{array}$ & Lebanon & Cross-sectional & 153 & 45 & General & Single item \\
\hline $\begin{array}{l}\text { Moljord et al., } \\
2011 \text { [125] }\end{array}$ & Norway & Cross-sectional & 1508 & 51 & General & $\begin{array}{l}\text { Single item (based on } \\
\text { Fordyce Happiness } \\
\text { Scale) }\end{array}$ \\
\hline $\begin{array}{l}\text { Neumann et al., } \\
2011 \text { [105] }\end{array}$ & Netherlands & Longitudinal & 452 & 45 & General & $\begin{array}{l}\text { Daily Mood Scale, an } \\
\text { Internet version of the } \\
\text { Electronic Mood } \\
\text { Device, Happiness } \\
\text { subscale }\end{array}$ \\
\hline $\begin{array}{l}\text { Veronese et al., } \\
2011 \text { [89] }\end{array}$ & Palestine & Cross-sectional & 216 & 45 & General & $\begin{array}{l}\text { Subjective Happiness } \\
\text { Scale (SHS) }\end{array}$ \\
\hline $\begin{array}{l}\text { Ali et al., } 2012 \\
\text { [90] }\end{array}$ & England & Cross-sectional & 7403 & 63 & General & Single item \\
\hline
\end{tabular}


Table A1. Cont.

\begin{tabular}{|c|c|c|c|c|c|c|}
\hline Study & Country & Study Design & $\mathbf{n}$ & Female $\%$ & Sample & $\begin{array}{c}\text { Happiness } \\
\text { Measurement }\end{array}$ \\
\hline $\begin{array}{l}\text { Chen et al., } 2012 \\
\text { [37] }\end{array}$ & Taiwan & Cross-sectional & 353 & 69 & General & Single item \\
\hline $\begin{array}{l}\text { Farmer and } \\
\text { Hanratty, } 2012 \\
{[76]}\end{array}$ & England & Cross-sectional & 3903 & no data & General & Single item \\
\hline $\begin{array}{l}\text { Meleddu et al., } \\
2012 \text { [124] }\end{array}$ & Italy & Cross-sectional & 782 & 58 & General & $\begin{array}{l}\text { Oxford Happiness } \\
\text { Inventory (OHI) }\end{array}$ \\
\hline $\begin{array}{l}\text { Oriel et al., } 2012 \\
\text { [61] }\end{array}$ & USA & Experiment & 23 & 43 & Mixed & $\begin{array}{l}\text { Piers-Harris } 2 \\
\text { Children's } \\
\text { Self-Concept Scale, } \\
\text { Happiness subscale }\end{array}$ \\
\hline $\begin{array}{l}\text { Potochnick et al., } \\
2012 \text { [24] }\end{array}$ & USA & Cross-sectional & 463 & 54 & General & $\begin{array}{l}\text { Profile of Mood States } \\
\text { (POMS) questionnaire, } \\
\text { Happiness subscale }\end{array}$ \\
\hline Shiue, 2012 [107] & Taiwan & Cross-sectional & 5586 & 49 & General & Single item \\
\hline $\begin{array}{l}\text { Su et al., } 2012 \\
\text { [148] }\end{array}$ & China & Cross-sectional & 1165 & 52 & General & $\begin{array}{l}\text { Oxford Happiness } \\
\text { Questionnaire-Short } \\
\text { Form (OHQ-sf) }\end{array}$ \\
\hline $\begin{array}{l}\text { van Campen } \\
\text { et al., } 2012 \text { [149] }\end{array}$ & Netherlands & Cross-sectional & 2101 & 53 & General & Single item \\
\hline $\begin{array}{l}\text { Abdel-Khalek, } \\
2013 \text { [47] }\end{array}$ & Qatar & Cross-sectional & 372 & 48 & General & Single item \\
\hline $\begin{array}{l}\text { Bartels et al., } 2013 \\
\text { [91] }\end{array}$ & Netherlands & Twin study & 10,610 & 70 & General & $\begin{array}{l}\text { Subjective Happiness } \\
\text { Scale (SHS) }\end{array}$ \\
\hline $\begin{array}{l}\text { Borges et al., } 2013 \\
\text { [111] }\end{array}$ & Portugal & Cross-sectional & 4877 & 50 & General & Single item \\
\hline $\begin{array}{l}\text { Brasseur et al., } \\
2013 \text { [49] }\end{array}$ & USA & Cross-sectional & 5676 & 84 & General & $\begin{array}{l}\text { Subjective Happiness } \\
\text { Scale (SHS) }\end{array}$ \\
\hline $\begin{array}{l}\text { Fararouei et al., } \\
2013 \text { [75] }\end{array}$ & Iran & Cross-sectional & 9867 & 100 & General & Single item \\
\hline $\begin{array}{l}\text { Hervás and } \\
\text { Vázquez, } 2013 \\
\text { [22] }\end{array}$ & $\begin{array}{l}\text { International } \\
\text { study } \\
\text { (10 countries) }\end{array}$ & Cross-sectional & 4052 & 50 & General & $\begin{array}{l}\text { Pemberton Happiness } \\
\text { Index }\end{array}$ \\
\hline $\begin{array}{l}\text { Yoo et al., } 2013 \\
\text { [157] }\end{array}$ & South Korea & Cross-sectional & 74,980 & 46 & General & Single item \\
\hline $\begin{array}{l}\text { Kiang and } \\
\text { Buchanan, } 2013 \\
\text { [99] }\end{array}$ & USA & Longitudinal & 180 & 58 & General & $\begin{array}{l}\text { Profile of Mood States } \\
\text { (POMS) questionnaire, } \\
\text { Happiness subscale }\end{array}$ \\
\hline $\begin{array}{l}\text { Murphy et al., } \\
2013 \text { [60] }\end{array}$ & USA & Experiment & 37 & 54 & General & $\begin{array}{l}\text { Piers-Harris Children's } \\
\text { Self-Concept Scale } \\
\text { (PHC-SCS), Happiness } \\
\text { subscale }\end{array}$ \\
\hline $\begin{array}{l}\text { Stiglbauer et al., } \\
2013 \text { [86] }\end{array}$ & Austria & Longitudinal & 393 & 70 & General & $\begin{array}{l}\text { WHO-5 Well-being } \\
\text { Index }\end{array}$ \\
\hline $\begin{array}{l}\text { Booker et al., } 2014 \\
\text { [110] }\end{array}$ & UK & Cross-sectional & 4899 & 48 & General & $\begin{array}{l}\text { Scale by Chan-Koo [no } \\
\text { definite name] }\end{array}$ \\
\hline $\begin{array}{l}\text { Choi et al., } 2014 \\
\text { [92] }\end{array}$ & South Korea & Cross-sectional & 1003 & 58 & General & $\begin{array}{l}\text { Oxford Happiness } \\
\text { Inventory (OHI) }\end{array}$ \\
\hline
\end{tabular}


Table A1. Cont.

\begin{tabular}{|c|c|c|c|c|c|c|}
\hline Study & Country & Study Design & $\mathbf{n}$ & Female \% & Sample & $\begin{array}{c}\text { Happiness } \\
\text { Measurement }\end{array}$ \\
\hline $\begin{array}{l}\text { Fischer et al., } \\
2014 \text { [96] }\end{array}$ & Australia & Longitudinal & 7223 & 100 & General & Single item \\
\hline $\begin{array}{l}\text { Park et al., } 2014 \\
\text { [62] }\end{array}$ & South Korea & Cross-sectional & 302 & 47 & General & Single item \\
\hline $\begin{array}{l}\text { Powdthavee and } \\
\text { Vernoit, } 2014 \\
{[129]}\end{array}$ & UK & Longitudinal & 3675 & no data & General & Single item \\
\hline $\begin{array}{l}\text { Vogler et al., } 2014 \\
\text { [67] }\end{array}$ & Germany & Cross-sectional & 30 & 46 & Clinical & $\begin{array}{l}\text { Gross National } \\
\text { Happiness Abridged } \\
\text { Survey (GNHAS) } \\
\text { questionnaire }\end{array}$ \\
\hline $\begin{array}{l}\text { Correa-Velez } \\
\text { et al., 2015 [72] }\end{array}$ & Australia & Longitudinal & 120 & 50 & General & Single item \\
\hline $\begin{array}{l}\text { da Rosa et al., } \\
2015 \text { [158] }\end{array}$ & Brazil & Cross-sectional & 1134 & 54 & General & $\begin{array}{l}\text { Subjective Happiness } \\
\text { Scale (SHS) }\end{array}$ \\
\hline $\begin{array}{l}\text { Disabato et al., } \\
2015 \text { [53] }\end{array}$ & $\begin{array}{l}\text { International } \\
\text { study (109 } \\
\text { countries) }\end{array}$ & Cross-sectional & 7617 & 79 & General & $\begin{array}{l}\text { Subjective Happiness } \\
\text { Scale (SHS) }\end{array}$ \\
\hline $\begin{array}{l}\text { Garaigordobil, } \\
2015 \text { [77] }\end{array}$ & Spain & Cross-sectional & 286 & 48 & General & $\begin{array}{l}\text { Oxford Happiness } \\
\text { Questionnaire (OHQ) }\end{array}$ \\
\hline $\begin{array}{l}\text { Haworth et al., } \\
2015 \text { [78] }\end{array}$ & UK & Twin study & 9394 & no data & General & $\begin{array}{l}\text { Subjective Happiness } \\
\text { Scale (SHS) }\end{array}$ \\
\hline $\begin{array}{l}\text { Heizomi et al., } \\
2015 \text { [98] }\end{array}$ & Iran & Cross-sectional & 403 & 50 & General & $\begin{array}{l}\text { Oxford Happiness } \\
\text { Questionnaire (OHQ) }\end{array}$ \\
\hline $\begin{array}{l}\text { Yeung et al., } 2015 \\
\text { [133] }\end{array}$ & Hong Kong & Cross-sectional & 712 & 46 & General & $\begin{array}{l}\text { Subjective Happiness } \\
\text { Scale (SHS) }\end{array}$ \\
\hline $\begin{array}{l}\text { Kelly et al., } 2015 \\
{[120]}\end{array}$ & Ireland & Cross-sectional & 6187 & 0 & General & Single item \\
\hline $\begin{array}{l}\text { Kern et al., } 2015 \\
\text { [57] }\end{array}$ & $\begin{array}{l}\text { Australia and } \\
\text { USA }\end{array}$ & Cross-sectional & 4484 & Median 38 & General & $\begin{array}{l}\text { EPOCH measure of } \\
\text { Adolescent Well-Being, } \\
\text { Happiness subscale }\end{array}$ \\
\hline $\begin{array}{l}\text { López-Pérez and } \\
\text { Wilson, } 2015 \text { [40] }\end{array}$ & Spain & Cross-sectional & 357 & $51-58$ & General & $\begin{array}{l}\text { Single item (based on } \\
\text { The Oxford Happiness } \\
\text { Questionnaire-Short } \\
\text { Form (OHQ-sf)) }\end{array}$ \\
\hline $\begin{array}{l}\text { Lardon et al., } \\
2015 \text { [100] }\end{array}$ & USA & Cross-sectional & 493 & 59 & General & Single item \\
\hline $\begin{array}{l}\text { Maciejewski et al., } \\
2015 \text { [80] }\end{array}$ & Netherlands & Longitudinal & 474 & 43 & General & $\begin{array}{l}\text { Daily Mood Scale, an } \\
\text { Internet version of the } \\
\text { Electronic Mood } \\
\text { Device, Happiness } \\
\text { subscale }\end{array}$ \\
\hline $\begin{array}{l}\text { Maher et al., } 2015 \\
{[41]}\end{array}$ & Australia & Cross-sectional & 70 & 64 & Clinical & Single item \\
\hline $\begin{array}{l}\text { Minkkinen et al., } \\
2015 \text { [82] }\end{array}$ & $\begin{array}{l}\text { International } \\
\text { study } \\
\text { (4 countries) }\end{array}$ & Cross-sectional & 3535 & no data & General & Single item \\
\hline
\end{tabular}


Table A1. Cont.

\begin{tabular}{|c|c|c|c|c|c|c|}
\hline Study & Country & Study Design & $\mathbf{n}$ & Female $\%$ & Sample & $\begin{array}{c}\text { Happiness } \\
\text { Measurement }\end{array}$ \\
\hline $\begin{array}{l}\text { Richards et al., } \\
2015 \text { [146] }\end{array}$ & $\begin{array}{l}\text { International } \\
\text { study } \\
\text { (15 countries) }\end{array}$ & Cross-sectional & 15,334 & 52 & General & Single item \\
\hline $\begin{array}{l}\text { Sheldon et al., } \\
2015 \text { [44] }\end{array}$ & $\begin{array}{l}\text { International } \\
\text { study } \\
\text { (40 countries) }\end{array}$ & Longitudinal & 755 & 82 & General & $\begin{array}{l}\text { Subjective Happiness } \\
\text { Scale (SHS) }\end{array}$ \\
\hline $\begin{array}{l}\text { So and Yeo, } 2015 \\
\text { [155] }\end{array}$ & South Korea & Cross-sectional & 73,850 & 48 & General & Single item \\
\hline $\begin{array}{l}\text { Tuchtenhagen } \\
\text { et al., } 2015 \text { [160] }\end{array}$ & Brazil & Cross-sectional & 1134 & 54 & General & $\begin{array}{l}\text { Subjective Happiness } \\
\text { Scale (SHS) }\end{array}$ \\
\hline $\begin{array}{l}\text { Wang et al., } 2015 \\
\text { [132] }\end{array}$ & China & Cross-sectional & 5854 & 52 & General & Single item \\
\hline $\begin{array}{l}\text { Abdollahi et al., } \\
2016 \text { [68] }\end{array}$ & Iran & Cross-sectional & 188 & 0 & General & $\begin{array}{l}\text { Oxford Happiness } \\
\text { Inventory (OHI) }\end{array}$ \\
\hline $\begin{array}{l}\text { Barke et al., } 2016 \\
\text { [36] }\end{array}$ & $\begin{array}{l}\text { International } \\
\text { study } \\
\text { (5 countries) }\end{array}$ & Cross-sectional & 73 & 71 & Clinical & $\begin{array}{l}\text { Subjective Happiness } \\
\text { Scale (SHS) }\end{array}$ \\
\hline $\begin{array}{l}\text { Brailovskaia and } \\
\text { Margraf, } 2016 \\
{[48]}\end{array}$ & Germany & Cross-sectional & 945 & 76 & General & $\begin{array}{l}\text { Subjective Happiness } \\
\text { Scale (SHS) }\end{array}$ \\
\hline $\begin{array}{l}\text { Dai and Chu, } \\
2016 \text { [73] }\end{array}$ & China & Cross-sectional & 448 & 51 & General & $\begin{array}{l}\text { Subjective Happiness } \\
\text { Scale (SHS) }\end{array}$ \\
\hline $\begin{array}{l}\text { Dales and } \\
\text { Cakmak, } 2016 \\
{[115]}\end{array}$ & Canada & Cross-sectional & 1883 & no data & General & Single item \\
\hline $\begin{array}{l}\text { Deserno et al., } \\
2016 \text { [52] }\end{array}$ & Netherlands & Cross-sectional & 2341 & 28 & Clinical & Single item \\
\hline $\begin{array}{l}\text { Fadda and Scalas, } \\
2016 \text { [94] }\end{array}$ & Italy & Cross-sectional & 1173 & 51 & General & $\begin{array}{l}\text { Oxford Happiness } \\
\text { Inventory }(\mathrm{OHI})\end{array}$ \\
\hline $\begin{array}{l}\text { Kelly et al., } 2016 \\
{[142]}\end{array}$ & UK & Longitudinal & 16,936 & 49 & General & $\begin{array}{l}\text { Scale by Chan-Koo [no } \\
\text { definite name] }\end{array}$ \\
\hline $\begin{array}{l}\text { Kye et al., } 2016 \\
{[151]}\end{array}$ & South Korea & Cross-sectional & 72,435 & 48 & General & Single item \\
\hline $\begin{array}{l}\text { Langer et al., } 2016 \\
\text { [79] }\end{array}$ & Chile & Cross-sectional & 665 & 58 & General & $\begin{array}{l}\text { Subjective Happiness } \\
\text { Scale (SHS) }\end{array}$ \\
\hline $\begin{array}{l}\text { Maciejewski et al., } \\
2016 \text { [102] }\end{array}$ & Netherlands & Longitudinal & 497 & 44 & Clinical & $\begin{array}{l}\text { Daily Mood Scale, an } \\
\text { Internet version of the } \\
\text { Electronic Mood } \\
\text { Device, Happiness } \\
\text { subscale }\end{array}$ \\
\hline $\begin{array}{l}\text { Maganto et al., } \\
2016 \text { [123] }\end{array}$ & Spain & Cross-sectional & 507 & 48 & General & $\begin{array}{l}\text { Oxford Happiness } \\
\text { Questionnaire (OHQ) }\end{array}$ \\
\hline $\begin{array}{l}\text { Mehrdadi et al., } \\
2016 \text { [103] }\end{array}$ & Iran & Cross-sectional & 500 & 46 & General & $\begin{array}{l}\text { Oxford Happiness } \\
\text { Inventory (OHI) }\end{array}$ \\
\hline $\begin{array}{l}\text { Ng Fat et al., } 2016 \\
\text { [141] }\end{array}$ & UK & Cross-sectional & 27,169 & 56 & General & Single item \\
\hline
\end{tabular}


Table A1. Cont.

\begin{tabular}{|c|c|c|c|c|c|c|}
\hline Study & Country & Study Design & $\mathbf{n}$ & Female \% & Sample & $\begin{array}{c}\text { Happiness } \\
\text { Measurement }\end{array}$ \\
\hline $\begin{array}{l}\text { Ngamaba, } 2016 \\
\text { [126] }\end{array}$ & $\begin{array}{l}\text { International } \\
\text { study } \\
\text { (59 countries) }\end{array}$ & Cross-sectional & 84,339 & 52 & General & Single item \\
\hline $\begin{array}{l}\text { Peasgood et al., } \\
2016[63]\end{array}$ & UK & Cross-sectional & 813 & 59 & Clinical & Single item \\
\hline $\begin{array}{l}\text { Saarikallio et al., } \\
2016 \text { [43] }\end{array}$ & Australia & Cross-sectional & 211 & no data & General & Single item \\
\hline $\begin{array}{l}\text { Sithey et al., } 2016 \\
\text { [154] }\end{array}$ & Bhutan & Cross-sectional & 6476 & 52 & General & Single item \\
\hline $\begin{array}{l}\text { Spithoven et al., } \\
2016 \text { [147] }\end{array}$ & $\begin{array}{l}\text { Belgium and } \\
\text { Netherlands }\end{array}$ & Cross-sectional & 1557 & 52 & General & Single item \\
\hline $\begin{array}{l}\text { Cebotari et al., } \\
2017 \text { [50] }\end{array}$ & Ghana & Longitudinal & 741 & 48 & General & Single item \\
\hline $\begin{array}{l}\text { Chen et al., } 2017 \\
\text { [11] }\end{array}$ & China & Cross-sectional & 45,858 & 46 & General & Single item \\
\hline $\begin{array}{l}\text { Cosma et al., } 2017 \\
{[114]}\end{array}$ & Scotland & Cross-sectional & 42,312 & 51 & General & Single item \\
\hline $\begin{array}{l}\text { Hong and Peltzer, } \\
2017 \text { [150] }\end{array}$ & Korea & Cross-sectional & 65,212 & 48 & General & Single item \\
\hline $\begin{array}{l}\text { Yadav et al., } 2017 \\
\text { [35] }\end{array}$ & India & Cross-sectional & 62 & 29 & Clinical & Single item \\
\hline $\begin{array}{l}\text { Yi and Kim, } 2017 \\
\text { [134] }\end{array}$ & South Korea & Cross-sectional & 65,426 & 48 & General & Single item \\
\hline $\begin{array}{l}\text { Islamova and } \\
\text { Islamov, } 2017 \text { [34] }\end{array}$ & Russia & Cross-sectional & 311 & 0 & General & Single item \\
\hline $\begin{array}{l}\text { Lim et al., } 2017 \\
\text { [143] }\end{array}$ & $\begin{array}{l}\text { International } \\
\text { study } \\
\text { ( } 5 \text { countries) }\end{array}$ & Cross-sectional & 11,944 & 66 & General & Single item \\
\hline $\begin{array}{l}\text { Liu et al., } 2017 \\
\text { [39] }\end{array}$ & China & Cross-sectional & 60 & 38 & Clinical & $\begin{array}{l}\text { Piers-Harris Children's } \\
\text { Self-Concept Scale } \\
\text { (PHC-SCS), Happiness } \\
\text { subscale }\end{array}$ \\
\hline $\begin{array}{l}\text { Loton and Waters, } \\
2017 \text { [122] }\end{array}$ & Australia & Cross-sectional & 11,138 & 41 & General & $\begin{array}{l}\text { EPOCH measure of } \\
\text { Adolescent Well-Being, } \\
\text { Happiness subscale }\end{array}$ \\
\hline $\begin{array}{l}\text { Pandya, } 2017 \\
{[106]}\end{array}$ & $\begin{array}{l}\text { International } \\
\text { study } \\
\text { (15 countries) }\end{array}$ & Experiment & 10,678 & 48 & General & $\begin{array}{l}\text { Humboldt Happiness } \\
\text { Scale-Adolescent } \\
\text { Version (HHSAV) }\end{array}$ \\
\hline $\begin{array}{l}\text { Park et al., } 2017 \\
\text { [145] }\end{array}$ & South Korea & Cross-sectional & 65,528 & 39 & General & Single item \\
\hline $\begin{array}{l}\text { Salavera et al., } \\
2017 \text { [84] }\end{array}$ & Spain & Cross-sectional & 543 & 50 & General & $\begin{array}{l}\text { Subjective Happiness } \\
\text { Scale (SHS) }\end{array}$ \\
\hline Su et al., 2017 [87] & China & Longitudinal & 897 & 54 & General & $\begin{array}{l}\text { Oxford Happiness } \\
\text { Questionnaire-Short } \\
\text { Form (OHQ-sf) }\end{array}$ \\
\hline $\begin{array}{l}\text { Whitehead et al., } \\
2017 \text { [156] }\end{array}$ & Scotland & Cross-sectional & 42,312 & 51 & General & Single item \\
\hline
\end{tabular}


Table A1. Cont.

\begin{tabular}{|c|c|c|c|c|c|c|}
\hline Study & Country & Study Design & $\mathbf{n}$ & Female \% & Sample & $\begin{array}{c}\text { Happiness } \\
\text { Measurement }\end{array}$ \\
\hline $\begin{array}{l}\text { Wootton et al., } \\
2017[108]\end{array}$ & UK & Twin study & 10,915 & 56 & General & $\begin{array}{l}\text { Subjective Happiness } \\
\text { Scale (SHS) }\end{array}$ \\
\hline $\begin{array}{l}\text { Ataeiasl et al., } \\
2018 \text { [12] }\end{array}$ & Iran & Cross-sectional & 1161 & 50 & General & $\begin{array}{l}\text { Oxford Happiness } \\
\text { Questionnaire (OHQ) }\end{array}$ \\
\hline $\begin{array}{l}\text { Bremer et al., } \\
2018 \text { [69] }\end{array}$ & Canada & Experiment & 362 & 48 & General & $\begin{array}{l}\text { Subjective Happiness } \\
\text { Scale (SHS) }\end{array}$ \\
\hline $\begin{array}{l}\text { Chao et al., } 2018 \\
\text { [71] }\end{array}$ & Taiwan & Longitudinal & 201 & 40 & General & $\begin{array}{l}\text { Positive and Negative } \\
\text { Affect Scale for } \\
\text { Children, Happiness } \\
\text { subscale }\end{array}$ \\
\hline $\begin{array}{l}\text { Delgado Floody } \\
\text { et al., } 2018 \text { [74] }\end{array}$ & Chile & Cross-sectional & 364 & 51 & General & Single item \\
\hline $\begin{array}{l}\text { He et al., } 2018 \\
{[119]}\end{array}$ & Nepal & Cross-sectional & 5226 & 100 & General & Single item \\
\hline $\begin{array}{l}\text { Hezomi and } \\
\text { Nadrian, } 2018 \\
{[56]}\end{array}$ & Iran & Cross-sectional & 289 & 100 & General & $\begin{array}{l}\text { Oxford Happiness } \\
\text { Questionnaire (OHQ) }\end{array}$ \\
\hline $\begin{array}{l}\text { Lai et al., } 2018 \\
\text { [121] }\end{array}$ & China & Cross-sectional & 726 & 45 & General & $\begin{array}{l}\text { Subjective Happiness } \\
\text { Scale (SHS) }\end{array}$ \\
\hline $\begin{array}{l}\text { Lee et al., } 2018 \\
\text { [58] }\end{array}$ & South Korea & Cross-sectional & 460 & 100 & General & Single item \\
\hline $\begin{array}{l}\text { Lemes et al., } 2018 \\
\text { [152] }\end{array}$ & Brazil & Cross-sectional & 1460 & 52 & General & $\begin{array}{l}\text { The Happiness } \\
\text { Measures (HM) }\end{array}$ \\
\hline $\begin{array}{l}\text { McChesney and } \\
\text { Toseeb, } 2018 \text { [81] }\end{array}$ & UK & Cross-sectional & 13,285 & 50 & Mixed & $\begin{array}{l}\text { Scale by Chan-Koo [no } \\
\text { definite name] }\end{array}$ \\
\hline $\begin{array}{l}\text { Park et al., } 2018 \\
\text { [127] }\end{array}$ & South Korea & Cross-sectional & 65,528 & 48 & General & Single item \\
\hline $\begin{array}{l}\text { Sfreddo et al., } \\
2018 \text { [130] }\end{array}$ & Brazil & Longitudinal & 1134 & 54 & General & $\begin{array}{l}\text { Single item (based on } \\
\text { Subjective Happiness } \\
\text { Scale (SHS)) }\end{array}$ \\
\hline $\begin{array}{l}\text { Shen et al., } 2018 \\
\text { [85] }\end{array}$ & Australia & Cross-sectional & 4582 & 69 & General & $\begin{array}{l}\text { Subjective Happiness } \\
\text { Scale (SHS) }\end{array}$ \\
\hline $\begin{array}{l}\text { Vaishnav et al., } \\
2018 \text { [45] }\end{array}$ & India & Experiment & 36 & 44 & General & Single item \\
\hline $\begin{array}{l}\text { Van Aart et al., } \\
2018 \text { [66] }\end{array}$ & Belgium & Longitudinal & 172 & 49 & General & Single item \\
\hline $\begin{array}{l}\text { Cho and Kim, } \\
2019 \text { [112] }\end{array}$ & South Korea & Cross-sectional & 62,276 & 49 & General & Single item \\
\hline $\begin{array}{l}\text { Choi et al., } 2019 \\
\text { [51] }\end{array}$ & South Korea & Cross-sectional & 268 & 53 & General & Scale by Han \\
\hline $\begin{array}{l}\text { Du et al., } 2019 \\
\text { [93] }\end{array}$ & China & Longitudinal & 3464 & 50 & General & Single item \\
\hline $\begin{array}{l}\text { Fariddanesh and } \\
\text { Rezaei, } 2019 \text { [140] }\end{array}$ & Iran & Cross-sectional & 381 & 45 & General & $\begin{array}{l}\text { Oxford Happiness } \\
\text { Questionnaire (OHQ) }\end{array}$ \\
\hline $\begin{array}{l}\text { Ferrer-Cascales } \\
\text { et al., } 2019 \text { [95] }\end{array}$ & Spain & Cross-sectional & 527 & 54 & General & $\begin{array}{l}\text { Subjective Happiness } \\
\text { Scale (SHS) }\end{array}$ \\
\hline
\end{tabular}


Table A1. Cont.

\begin{tabular}{|c|c|c|c|c|c|c|}
\hline Study & Country & Study Design & $\mathbf{n}$ & Female \% & Sample & $\begin{array}{c}\text { Happiness } \\
\text { Measurement }\end{array}$ \\
\hline $\begin{array}{l}\text { Fosco and } \\
\text { Lydon-Staley, } \\
2019[54]\end{array}$ & USA & Longitudinal & 151 & 62 & General & $\begin{array}{l}\text { Profile of Mood } \\
\text { States-Adolescent } \\
\text { version (POMS-A), } \\
\text { Positive mood subscale }\end{array}$ \\
\hline $\begin{array}{l}\text { Freire and } \\
\text { Ferreira, } 2019 \text { [4] }\end{array}$ & Portugal & Cross-sectional & 910 & 51 & General & $\begin{array}{l}\text { Subjective Happiness } \\
\text { Scale (SHS) }\end{array}$ \\
\hline $\begin{array}{l}\text { Giacomo et al., } \\
2019 \text { [55] }\end{array}$ & Italy & Cross-sectional & 1221 & 82 & General & $\begin{array}{l}\text { EPOCH measure of } \\
\text { Adolescent Well-Being, } \\
\text { Happiness subscale }\end{array}$ \\
\hline $\begin{array}{l}\text { Guerra- } \\
\text { Bustamante et al., } \\
2019 \text { [97] }\end{array}$ & Spain & Cross-sectional & 646 & 48 & General & $\begin{array}{l}\text { Oxford Happiness } \\
\text { Questionnaire (OHQ) }\end{array}$ \\
\hline $\begin{array}{l}\text { Lin et al., } 2019 \\
{[101]}\end{array}$ & Taiwan & Longitudinal & 2571 & 49 & General & Single item \\
\hline $\begin{array}{l}\text { Lung et al., } 2019 \\
\text { [144] }\end{array}$ & Taiwan & Cross-sectional & 1561 & 45 & Clinical & $\begin{array}{l}\text { Oxford Happiness } \\
\text { Questionnaire-Short } \\
\text { Form (OHQ-sf) }\end{array}$ \\
\hline $\begin{array}{l}\text { Lung and Shu, } \\
2019 \text { [159] }\end{array}$ & Taiwan & Cross-sectional & 17,694 & 48 & General & $\begin{array}{l}\text { Oxford Happiness } \\
\text { Questionnaire-Short } \\
\text { Form (OHQ-sf) }\end{array}$ \\
\hline $\begin{array}{l}\text { Mercado et al., } \\
2019 \text { [104] }\end{array}$ & USA & Longitudinal & 337 & 50 & General & $\begin{array}{l}\text { The Profile of Mood } \\
\text { States (POMS) } \\
\text { questionnaire, } \\
\text { Happiness subscale }\end{array}$ \\
\hline $\begin{array}{l}\text { Michels et al., } \\
2019 \text { [42] }\end{array}$ & Belgium & Cross-sectional & 93 & 48 & General & Single item \\
\hline $\begin{array}{l}\text { Moore et al., } 2019 \\
\text { [83] }\end{array}$ & USA & Longitudinal & 144 & 56 & General & $\begin{array}{l}\text { Positive and Negative } \\
\text { Affect Scale for } \\
\text { Children (PANAS-C), } \\
\text { Daily happiness } \\
\text { subscale }\end{array}$ \\
\hline $\begin{array}{l}\text { Quy et al., } 2019 \\
\text { [64] }\end{array}$ & England & Cross-sectional & 2566 & 49 & General & Scale by Quy \\
\hline $\begin{array}{l}\text { Schacter and } \\
\text { Margolin, } 2019 \\
\text { [65] }\end{array}$ & USA & Longitudinal & 119 & 48 & General & $\begin{array}{l}\text { Scale by Schacter and } \\
\text { Margolin }\end{array}$ \\
\hline $\begin{array}{l}\text { Twenge and } \\
\text { Campbell, } 2019 \\
\text { [88] }\end{array}$ & UK & Cross-sectional & 221,096 & no data & General & Single item \\
\hline $\begin{array}{l}\text { Viner et al., } 2019 \\
\text { [131] }\end{array}$ & UK & Longitudinal & 12,866 & 51 & General & Single item \\
\hline $\begin{array}{l}\text { Zeng and Kern, } \\
2019 \text { [137] }\end{array}$ & China & Cross-sectional & 17,854 & 46 & General & $\begin{array}{l}\text { EPOCH measure of } \\
\text { Adolescent Well-Being, } \\
\text { Happiness subscale }\end{array}$ \\
\hline $\begin{array}{l}\text { Zhao et al., } 2019 \\
\text { [138] }\end{array}$ & China & Cross-sectional & 2140 & 47 & General & $\begin{array}{l}\text { Subjective Happiness } \\
\text { Scale (SHS) }\end{array}$ \\
\hline
\end{tabular}




\section{Appendix B}

Table A2. Analysis of the methodological quality of the studies included in the systematic review.

\begin{tabular}{|c|c|c|c|c|c|c|}
\hline \multirow[b]{2}{*}{ Study } & \multicolumn{5}{|c|}{ Quality Criteria } & \multirow{2}{*}{$\begin{array}{l}\text { Total Quality } \\
\text { Score }\end{array}$} \\
\hline & Representativeness & $\begin{array}{l}\text { Response } \\
\text { Rate }\end{array}$ & $\begin{array}{l}\text { Gender } \\
\text { Balance }\end{array}$ & $\begin{array}{l}\text { Sample } \\
\text { Size }\end{array}$ & Measurement & \\
\hline Abdel-Khalek, 2011 [46] & 1 & 1 & 3 & 2 & 2 & 9 \\
\hline Abdel-Khalek, 2013 [47] & 1 & 1 & 3 & 2 & 2 & 9 \\
\hline Abdollahi et al., 2016 [68] & 1 & 3 & 1 & 2 & 3 & 10 \\
\hline Ali et al., 2012 [90] & 2 & 2 & 2 & 3 & 2 & 11 \\
\hline Ataeiasl et al., 2018 [12] & 2 & 3 & 3 & 3 & 3 & 14 \\
\hline Barke et al., 2016 [36] & 1 & 1 & 2 & 1 & 3 & 8 \\
\hline Bartels et al., 2010 [109] & 2 & 1 & 3 & 3 & 3 & 12 \\
\hline Bartels et al., 2013 [91] & 2 & 1 & 2 & 3 & 3 & 11 \\
\hline Bolat et al., 2011 [23] & 1 & 1 & 3 & 1 & 3 & 9 \\
\hline Booker et al., 2014 [110] & 3 & 2 & 3 & 3 & 1 & 12 \\
\hline Borges et al., 2013 [111] & 3 & 1 & 3 & 3 & 2 & 12 \\
\hline $\begin{array}{l}\text { Brailovskaia and Margraf, } \\
2016 \text { [48] }\end{array}$ & 2 & 1 & 1 & 2 & 3 & 9 \\
\hline Brasseur et al., 2013 [49] & 1 & 1 & 1 & 3 & 3 & 9 \\
\hline Bremer et al., 2018 [69] & 1 & 1 & 3 & 2 & 3 & 10 \\
\hline Burrow and Hill, 2011 [70] & 1 & 1 & 3 & 2 & 3 & 10 \\
\hline Cebotari et al., 2017 [50] & 1 & 1 & 3 & 2 & 2 & 9 \\
\hline Chao et al., 2018 [71] & 1 & 1 & 3 & 2 & 3 & 10 \\
\hline Chen et al., 2012 [37] & 1 & 1 & 2 & 2 & 2 & 8 \\
\hline Chen et al., 2017 [11] & 2 & 3 & 3 & 3 & 2 & 13 \\
\hline Cho and Kim, 2019 [112] & 3 & 1 & 3 & 3 & 2 & 12 \\
\hline Choi et al., 2014 [92] & 1 & 1 & 3 & 3 & 3 & 11 \\
\hline Choi et al., 2019 [51] & 2 & 1 & 3 & 2 & 1 & 9 \\
\hline Cooper et al., 2011 [113] & 2 & 2 & 3 & 3 & 2 & 12 \\
\hline Correa-Velez et al., 2015 [72] & 1 & 2 & 3 & 2 & 2 & 10 \\
\hline Cosma et al., 2017 [114] & 3 & 1 & 3 & 3 & 2 & 12 \\
\hline da Rosa et al., 2015 [158] & 3 & 3 & 3 & 3 & 3 & 15 \\
\hline Dai and Chu, 2016 [73] & 1 & 1 & 3 & 2 & 3 & 10 \\
\hline $\begin{array}{l}\text { Dales and Cakmak, } 2016 \\
\text { [115] }\end{array}$ & 3 & 3 & 1 & 3 & 2 & 12 \\
\hline de Bruin et al., 2011 [139] & 2 & 3 & 3 & 2 & 3 & 13 \\
\hline $\begin{array}{l}\text { Delgado Floody et al., } 2018 \\
\text { [74] }\end{array}$ & 2 & 1 & 3 & 2 & 2 & 10 \\
\hline Deserno et al., 2016 [52] & 1 & 1 & 2 & 3 & 2 & 9 \\
\hline Disabato et al., 2015 [53] & 1 & 1 & 1 & 3 & 3 & 9 \\
\hline Du et al., 2019 [93] & 3 & 2 & 1 & 3 & 2 & 11 \\
\hline Fadda and Scalas, 2016 [94] & 1 & 1 & 3 & 3 & 3 & 11 \\
\hline
\end{tabular}


Table A2. Cont.

\begin{tabular}{|c|c|c|c|c|c|c|}
\hline \multirow[b]{2}{*}{ Study } & \multicolumn{5}{|c|}{ Quality Criteria } & \multirow[b]{2}{*}{$\begin{array}{l}\text { Total Quality } \\
\text { Score }\end{array}$} \\
\hline & Representativeness & $\begin{array}{l}\text { Response } \\
\text { Rate }\end{array}$ & $\begin{array}{l}\text { Gender } \\
\text { Balance }\end{array}$ & $\begin{array}{l}\text { Sample } \\
\text { Size }\end{array}$ & $\overline{\text { Measurement }}$ & \\
\hline Fararouei et al., 2013 [75] & 1 & 3 & 1 & 3 & 2 & 10 \\
\hline $\begin{array}{l}\text { Fariddanesh and Rezaei, } \\
2019 \text { [140] }\end{array}$ & 2 & 3 & 3 & 2 & 3 & 13 \\
\hline $\begin{array}{l}\text { Farmer and Hanratty, } 2012 \\
\text { [76] }\end{array}$ & 3 & 1 & 1 & 3 & 2 & 10 \\
\hline $\begin{array}{l}\text { Ferrer-Cascales et al., } 2019 \\
\text { [95] }\end{array}$ & 2 & 1 & 3 & 2 & 3 & 11 \\
\hline Fischer et al., 2014 [96] & 2 & 3 & 1 & 3 & 2 & 11 \\
\hline $\begin{array}{l}\text { Fonseca and Matos, } 2011 \\
\text { [116] }\end{array}$ & 3 & 1 & 3 & 3 & 2 & 12 \\
\hline $\begin{array}{l}\text { Fosco and Lydon-Staley, } \\
2019[54]\end{array}$ & 1 & 1 & 2 & 2 & 3 & 9 \\
\hline Freire and Ferreira, 2019 [4] & 2 & 1 & 3 & 2 & 3 & 11 \\
\hline Garaigordobil, 2015 [77] & 1 & 1 & 3 & 2 & 3 & 10 \\
\hline $\begin{array}{l}\text { Gaspar de Matos et al., } 2010 \\
\text { [117] }\end{array}$ & 3 & 1 & 3 & 3 & 2 & 12 \\
\hline Giacomo et al., 2019 [55] & 1 & 1 & 1 & 3 & 3 & 9 \\
\hline $\begin{array}{l}\text { González-Quiñones and } \\
\text { Restrepo-Chavarriaga, } 2010 \\
\text { [118] }\end{array}$ & 3 & 1 & 3 & 3 & 2 & 12 \\
\hline $\begin{array}{l}\text { Guerra-Bustamante et al., } \\
2019 \text { [97] }\end{array}$ & 2 & 1 & 3 & 2 & 3 & 11 \\
\hline Haworth et al., 2015 [78] & 2 & 1 & 1 & 3 & 3 & 10 \\
\hline He et al., 2018 [119] & 3 & 3 & 1 & 3 & 2 & 12 \\
\hline Heizomi et al., 2015 [98] & 2 & 1 & 3 & 2 & 3 & 11 \\
\hline $\begin{array}{l}\text { Hervás and Vázquez, } 2013 \\
\text { [22] }\end{array}$ & 2 & 1 & 3 & 3 & 3 & 12 \\
\hline $\begin{array}{l}\text { Hezomi and Nadrian, } 2018 \\
\text { [56] }\end{array}$ & 2 & 1 & 1 & 2 & 3 & 9 \\
\hline Hong and Peltzer, 2017 [150] & 3 & 3 & 3 & 3 & 2 & 14 \\
\hline Yadav et al., 2017 [35] & 1 & 1 & 2 & 1 & 2 & 7 \\
\hline Yeung et al., 2015 [133] & 1 & 3 & 3 & 2 & 3 & 12 \\
\hline Yi and Kim, 2017 [134] & 3 & 1 & 3 & 3 & 2 & 12 \\
\hline Yoo et al., 2013 [157] & 3 & 3 & 3 & 3 & 2 & 14 \\
\hline $\begin{array}{l}\text { Islamova and Islamov, } 2017 \\
\text { [34] }\end{array}$ & 1 & 1 & 1 & 2 & 2 & 7 \\
\hline Yu et al., 2011 [136] & 3 & 1 & 3 & 3 & 2 & 12 \\
\hline Yu et al., 2012 [135] & 3 & 1 & 3 & 3 & 2 & 12 \\
\hline Kelly et al., 2015 [120] & 3 & 3 & 1 & 3 & 2 & 12 \\
\hline Kelly et al., 2016 [142] & 3 & 3 & 3 & 3 & 1 & 13 \\
\hline Kern et al., 2015 [57] & 1 & 1 & 1 & 3 & 3 & 9 \\
\hline
\end{tabular}


Table A2. Cont.

\begin{tabular}{|c|c|c|c|c|c|c|}
\hline \multirow[b]{2}{*}{ Study } & \multicolumn{5}{|c|}{ Quality Criteria } & \multirow[b]{2}{*}{$\begin{array}{l}\text { Total Quality } \\
\text { Score }\end{array}$} \\
\hline & Representativeness & $\begin{array}{l}\text { Response } \\
\text { Rate }\end{array}$ & $\begin{array}{l}\text { Gender } \\
\text { Balance }\end{array}$ & $\begin{array}{l}\text { Sample } \\
\text { Size }\end{array}$ & Measurement & \\
\hline $\begin{array}{l}\text { Kiang and Buchanan, } 2013 \\
\text { [99] }\end{array}$ & 1 & 2 & 3 & 2 & 3 & 11 \\
\hline Kye et al., 2016 [151] & 3 & 3 & 3 & 3 & 2 & 14 \\
\hline Lai et al., 2018 [121] & 1 & 3 & 3 & 2 & 3 & 12 \\
\hline Langer et al., 2016 [79] & 1 & 1 & 3 & 2 & 3 & 10 \\
\hline Lardon et al., 2015 [100] & 3 & 1 & 3 & 2 & 2 & 11 \\
\hline Lázaro et al., 2011 [38] & 1 & 1 & 1 & 2 & 3 & 8 \\
\hline Lee et al., 2018 [58] & 1 & 3 & 1 & 2 & 2 & 9 \\
\hline Lemes et al., 2018 [152] & 2 & 3 & 3 & 3 & 3 & 14 \\
\hline Levin, 2011 [153] & 3 & 3 & 3 & 3 & 2 & 14 \\
\hline Lim et al., 2017 [143] & 3 & 3 & 2 & 3 & 2 & 13 \\
\hline Lin et al., 2019 [101] & 2 & 1 & 3 & 3 & 2 & 11 \\
\hline Liu et al., 2017 [39] & 1 & 1 & 2 & 1 & 3 & 8 \\
\hline $\begin{array}{l}\text { López-Pérez and Wilson, } \\
2015 \text { [40] }\end{array}$ & 1 & 2 & 1 & 2 & 2 & 8 \\
\hline Loton and Waters, 2017 [122] & 2 & 1 & 3 & 3 & 3 & 12 \\
\hline Lung and Shu, 2019 [159] & 3 & 3 & 3 & 3 & 3 & 15 \\
\hline Lung et al., 2019 [144] & 3 & 1 & 3 & 3 & 3 & 13 \\
\hline Maciejewski et al., 2015 [80] & 1 & 1 & 3 & 2 & 3 & 10 \\
\hline Maciejewski et al., 2016 [102] & 1 & 2 & 3 & 2 & 3 & 11 \\
\hline Maganto et al., 2016 [123] & 3 & 1 & 3 & 2 & 3 & 12 \\
\hline Maher et al., 2015 [41] & 1 & 2 & 2 & 1 & 2 & 8 \\
\hline Mahfoud et al., 2011 [59] & 1 & 1 & 3 & 2 & 2 & 9 \\
\hline $\begin{array}{l}\text { McChesney and Toseeb, } 2018 \\
\text { [81] }\end{array}$ & 2 & 1 & 3 & 3 & 1 & 10 \\
\hline Mehrdadi et al., 2016 [103] & 2 & 1 & 3 & 2 & 3 & 11 \\
\hline Meleddu et al., 2012 [124] & 1 & 3 & 3 & 2 & 3 & 12 \\
\hline Mercado et al., 2019 [104] & 1 & 2 & 3 & 2 & 3 & 11 \\
\hline Michels et al., 2019 [42] & 1 & 1 & 3 & 1 & 2 & 8 \\
\hline Minkkinen et al., 2015 [82] & 3 & 1 & 1 & 3 & 2 & 10 \\
\hline Moljord et al., 2011 [125] & 2 & 2 & 3 & 3 & 2 & 12 \\
\hline Moore et al., 2019 [83] & 1 & 1 & 3 & 2 & 3 & 10 \\
\hline Murphy et al., 2013 [60] & 1 & 1 & 3 & 1 & 3 & 9 \\
\hline Neumann et al., 2011 [105] & 2 & 1 & 3 & 2 & 3 & 11 \\
\hline Ng Fat et al., 2016 [141] & 3 & 2 & 3 & 3 & 2 & 13 \\
\hline Ngamaba, 2016 [126] & 3 & 1 & 3 & 3 & 2 & 12 \\
\hline Oriel et al., 2012 [61] & 1 & 1 & 3 & 1 & 3 & 9 \\
\hline Pandya, 2017 [106] & 1 & 1 & 3 & 3 & 3 & 11 \\
\hline Park et al., 2014 [62] & 1 & 1 & 3 & 2 & 2 & 9 \\
\hline
\end{tabular}


Table A2. Cont.

\begin{tabular}{|c|c|c|c|c|c|c|}
\hline \multirow[b]{2}{*}{ Study } & \multicolumn{5}{|c|}{ Quality Criteria } & \multirow[b]{2}{*}{$\begin{array}{l}\text { Total Quality } \\
\text { Score }\end{array}$} \\
\hline & Representativeness & $\begin{array}{l}\text { Response } \\
\text { Rate }\end{array}$ & $\begin{array}{l}\text { Gender } \\
\text { Balance }\end{array}$ & $\begin{array}{l}\text { Sample } \\
\text { Size }\end{array}$ & Measurement & \\
\hline Park et al., 2017 [145] & 3 & 3 & 2 & 3 & 2 & 13 \\
\hline Park et al., 2018 [127] & 3 & 1 & 3 & 3 & 2 & 12 \\
\hline Peasgood et al., 2016 [63] & 1 & 1 & 3 & 2 & 2 & 9 \\
\hline Phongsavan et al., 2010 [128] & 2 & 2 & 3 & 3 & 2 & 12 \\
\hline Potochnick et al., 2012 [24] & 1 & 1 & 3 & 2 & 3 & 10 \\
\hline $\begin{array}{l}\text { Powdthavee and Vernoit, } \\
2014 \text { [129] }\end{array}$ & 3 & 3 & 1 & 3 & 2 & 12 \\
\hline Quy et al., 2019 [64] & 3 & 1 & 1 & 3 & 1 & 9 \\
\hline Richards et al., 2015 [146] & 3 & 2 & 3 & 3 & 2 & 13 \\
\hline Saarikallio et al., 2016 [43] & 2 & 1 & 1 & 2 & 2 & 8 \\
\hline Salavera et al., 2017 [84] & 1 & 1 & 3 & 2 & 3 & 10 \\
\hline $\begin{array}{l}\text { Schacter and Margolin, } 2019 \\
\text { [65] }\end{array}$ & 1 & 2 & 3 & 2 & 1 & 9 \\
\hline Sfreddo et al., 2018 [130] & 2 & 2 & 3 & 3 & 2 & 12 \\
\hline Sheldon et al., 2015 [44] & 1 & 1 & 1 & 2 & 3 & 8 \\
\hline Shen et al., 2018 [85] & 1 & 1 & 2 & 3 & 3 & 10 \\
\hline Shiue, 2012 [107] & 2 & 1 & 3 & 3 & 2 & 11 \\
\hline Sithey et al., 2016 [154] & 3 & 3 & 3 & 3 & 2 & 14 \\
\hline So and Yeo, 2015 [155] & 3 & 3 & 3 & 3 & 2 & 14 \\
\hline Spithoven et al., 2016 [147] & 2 & 3 & 3 & 3 & 2 & 13 \\
\hline Stiglbauer et al., 2013 [86] & 1 & 2 & 2 & 2 & 3 & 10 \\
\hline Su et al., 2012 [148] & 1 & 3 & 3 & 3 & 3 & 13 \\
\hline Su et al., 2017 [87] & 1 & 1 & 3 & 2 & 3 & 10 \\
\hline $\begin{array}{l}\text { Tuchtenhagen et al., } 2015 \\
\text { [160] }\end{array}$ & 3 & 3 & 3 & 3 & 3 & 15 \\
\hline $\begin{array}{l}\text { Twenge and Campbell, } 2019 \\
\text { [88] }\end{array}$ & 3 & 1 & 1 & 3 & 2 & 10 \\
\hline Vaishnav et al., 2018 [45] & 1 & 1 & 3 & 1 & 2 & 8 \\
\hline Van Aart et al., 2018 [66] & 1 & 1 & 3 & 2 & 2 & 9 \\
\hline van Campen et al., 2012 [149] & 3 & 2 & 3 & 3 & 2 & 13 \\
\hline Veronese et al., 2011 [89] & 1 & 1 & 3 & 2 & 3 & 10 \\
\hline Viner et al., 2019 [131] & 3 & 1 & 3 & 3 & 2 & 12 \\
\hline Vogler et al., 2014 [67] & 1 & 1 & 3 & 1 & 3 & 9 \\
\hline Wang et al., 2015 [132] & 3 & 1 & 3 & 3 & 2 & 12 \\
\hline Whitehead et al., 2017 [156] & 3 & 3 & 3 & 3 & 2 & 14 \\
\hline Wootton et al., 2017 [108] & 1 & 1 & 3 & 3 & 3 & 11 \\
\hline Zeng and Kern, 2019 [137] & 2 & 1 & 3 & 3 & 3 & 12 \\
\hline Zhao et al., 2019 [138] & 2 & 1 & 3 & 3 & 3 & 12 \\
\hline
\end{tabular}




\section{Appendix C}

Table A3. Single-item measurements.

\begin{tabular}{|c|c|c|}
\hline Study & Question & Response Options \\
\hline Abdel-Khalek, 2011 [46] & Single-item self-rating scale & 0 (minimum) to 10 (maximum) \\
\hline Abdel-Khalek, 2013 [47] & To what degree do you feel happy in general? & 1 to 10 \\
\hline Ali et al., 2012 [90] & $\begin{array}{l}\text { Taking all things together, how would you say } \\
\text { you were these days? }\end{array}$ & $\begin{array}{ll} & \text { very happy } \\
\text { - } & \text { fairly happy } \\
\text { - } & \text { not too happy }\end{array}$ \\
\hline Borges et al., 2013 [111] & $\begin{array}{l}\text { Adolescents were asked to select the degree of } \\
\text { happiness they felt in relation to life at that } \\
\text { moment in time. }\end{array}$ & $\begin{array}{l}\text { Four points from 'I feel unhappy' to 'I } \\
\text { feel happy' }\end{array}$ \\
\hline Cebotari et al., 2017 [50] & How happy they consider themselves & From 1 to 5 (higher is better) \\
\hline Chen et al., 2012 [37] & $\begin{array}{l}\text { On the whole, do you feel that you are having a } \\
\text { happy life now? }\end{array}$ & $\begin{array}{l}\text { from } 1 \text { (strongly disagree) to } 7 \text { (strongly } \\
\text { agree) }\end{array}$ \\
\hline Chen et al., 2017 [11] & All things considered, you think you are & $\begin{array}{ll}\text { - } & \text { very happy } \\
\text { - } & \text { happy } \\
\text { - } & \text { not very happy } \\
\text { - } & \text { not happy at all }\end{array}$ \\
\hline Cho and Kim, 2019 [112] & Subjective happiness & $\begin{array}{ll}- & \text { happy } \\
- & \text { moderate } \\
- & \text { unhappy }\end{array}$ \\
\hline Cooper et al., 2011 [113] & $\begin{array}{l}\text { Taking all things together, how would you say } \\
\text { you are these days? }\end{array}$ & $\begin{array}{ll}- & \text { very happy } \\
\text { - } & \text { fairly happy } \\
\text { - } & \text { not too happy }\end{array}$ \\
\hline Correa-Velez et al., 2015 [72] & How happy are you now? & $\begin{array}{l}\text { From } 1 \text { (not at all happy) to } 4 \text { (very } \\
\text { happy) }\end{array}$ \\
\hline Cosma et al., 2017 [114] & How they feel about their lives at the moment & $\begin{array}{l}\text { - } \quad \text { I'm not happy at all. } \\
\text { - } \quad \text { I don't feel very happy. } \\
\text { - } \quad \text { I feel quite happy. } \\
\text { - } \quad \text { I feel very happy. }\end{array}$ \\
\hline Dales and Cakmak, 2016 [115] & $\begin{array}{l}\text { Would you describe yourself as being usually } \\
\text { happy and interested in life? }\end{array}$ & $\begin{array}{ll}\text { - } & \text { somewhat happy } \\
\text { - } & \text { somewhat unhappy } \\
\text { - } & \text { unhappy with little interest in life } \\
\text { - } & \text { so unhappy that life is not } \\
& \text { worthwhile }\end{array}$ \\
\hline Delgado Floody et al., 2018 [74] & Am I a happy person? & $\begin{array}{ll}- & \text { yes } \\
- & \text { no }\end{array}$ \\
\hline Deserno et al., 2016 [52] & How happy are you? & From 1 (not at all) to 5 (very much) \\
\hline Du et al., 2019 [93] & How happy do you feel? & $\begin{array}{l}\text { Time 1: from } 1 \text { (very unhappy) to } 5 \text { (very } \\
\text { happy)Time 2: from } 0 \text { (very unhappy) to } \\
11 \text { (very happy) }\end{array}$ \\
\hline Fararouei et al., 2013 [75] & $\begin{array}{l}\text { How happy are you at present with your life as a } \\
\text { whole? }\end{array}$ & 0 to 10 \\
\hline Farmer and Hanratty, 2012 [76] & I feel happy about life. & $\begin{array}{ll}- & \text { yes } \\
- & \text { no } \\
\end{array}$ \\
\hline Fischer et al., 2014 [96] & $\begin{array}{l}\text { How would you say you feel these days? Would } \\
\text { you say you are: }\end{array}$ & $\begin{array}{ll}\bullet & \text { very happy } \\
\bullet & \text { happy } \\
\bullet & \text { unhappy } \\
\end{array}$ \\
\hline Fonseca and Matos, 2011 [116] & Would you say, in general, that your life is: & $\begin{array}{ll}\text { - } & \text { very happy } \\
\text { - } & \text { happy } \\
\text { - } & \text { not very happy } \\
\text { - } & \text { unhappy }\end{array}$ \\
\hline
\end{tabular}


Table A3. Cont.

\begin{tabular}{|c|c|c|}
\hline Study & Question & Response Options \\
\hline Gaspar de Matos et al., 2010 [117] & $\begin{array}{l}\text { In general, how do you feel about your life at } \\
\text { present? }\end{array}$ & $\begin{array}{ll}\text { - } & \text { I'm not happy at all. } \\
\text { - } & \text { I don't feel very happy. } \\
\text { - } & \text { I feel quite happy. } \\
\text { - } & \text { I feel very happy. }\end{array}$ \\
\hline $\begin{array}{l}\text { González-Quiñones and } \\
\text { Restrepo-Chavarriaga, } 2010 \text { [118] }\end{array}$ & State of mind & $\begin{array}{ll} & \text { happy } \\
\text { - } & \text { normal } \\
\text { - } & \text { sad } \\
\end{array}$ \\
\hline He et al., 2018 [119] & Taking all things together, would you say you are & $\begin{array}{ll} & \text { very happy } \\
\text { - } & \text { somewhat happy } \\
\text { - } & \text { neither happy nor unhappy } \\
\text { - } & \text { somewhat unhappy } \\
\text { - } & \text { very unhappy }\end{array}$ \\
\hline Hong and Peltzer, 2017 [150] & How happy do you usually feel? & $\begin{array}{ll}\text { - } & \text { very happy } \\
\text { - } & \text { happy } \\
\text { - } & \text { average } \\
\text { - } & \text { unhappy } \\
\text { - } & \text { very unhappy }\end{array}$ \\
\hline
\end{tabular}

Islamova and Islamov, 2017 [34]

happiness measured at Actual level, Desired level, and Achievable level
The scale was a vertical $12 \mathrm{~cm}$ line on which the respondents made the signs.

\begin{tabular}{|c|c|c|}
\hline Kelly et al., 2015 [120] & $\begin{array}{l}\text { In general, how do you feel about your life at } \\
\text { present? }\end{array}$ & $\begin{array}{ll}\text { - } & \text { very happy } \\
\text { - } & \text { quite happy } \\
\text { - } & \text { don't feel very happy } \\
\text { - } & \text { not happy at all }\end{array}$ \\
\hline Kye et al., 2016 [151] & $\begin{array}{l}\text { In general, how would you describe your } \\
\text { happiness? }\end{array}$ & $\begin{array}{ll}\text { - } & \text { very happy } \\
\text { - } & \text { a little happy } \\
\text { - } & \text { neutral } \\
\text { - } & \text { a little unhappy } \\
\text { - } & \text { very unhappy }\end{array}$ \\
\hline Lardon et al., 2015 [100] & $\begin{array}{l}\text { Consider how life is currently going for you. } \\
\text { Overall, how happy are you with your life? }\end{array}$ & $\begin{array}{ll}\text { - } & \text { very unhappy } \\
\text { - } & \text { somewhat unhappy } \\
\text { - } & \text { somewhat happy } \\
\text { - } & \text { very happy }\end{array}$ \\
\hline Lee et al., 2018 [58] & How happy do you think you are in general? & From 1 (very happy) to 5 (very unhappy) \\
\hline Levin, 2011 [153] & $\begin{array}{l}\text { In general, how do you feel about your life at the } \\
\text { moment? }\end{array}$ & $\begin{array}{l}\text { - } \quad \text { I feel very happy. } \\
\text { - } \quad \text { I feel quite happy. } \\
\text { - } \quad \text { I don't feel very happy. } \\
\text { - } \quad \text { I'm not happy at all. }\end{array}$ \\
\hline Lim et al., 2017 [143] & How happy they were & From 1 (very happy) to 5 (very unhappy) \\
\hline Lin et al., 2019 [101] & In general, are you happy lately? & $\begin{array}{ll}\text { - } & \text { very unhappy } \\
\text { - } & \text { unhappy } \\
\text { - } & \text { happy } \\
\text { - } & \text { very happy }\end{array}$ \\
\hline López-Pérez and Wilson, 2015 [40] & Do you feel happy in general? & $\begin{array}{l}\text { From } 0 \text { (not at all) to } 10 \text { (extremely), taken } \\
\text { from the General Happiness Single-Item } \\
\text { Scale (GHS-IS) }\end{array}$ \\
\hline Maher et al., 2015 [41] & $\begin{array}{l}\text { Taking all things together, would you say you } \\
\text { are... }\end{array}$ & $\begin{array}{ll}\text { - } & \text { very happy } \\
\text { - } & \text { quite happy } \\
\text { - } & \text { not very happy } \\
\text { - } & \text { not at all happy }\end{array}$ \\
\hline
\end{tabular}


Table A3. Cont.

\begin{tabular}{|c|c|c|}
\hline Study & Question & Response Options \\
\hline Mahfoud et al., 2011 [59] & A question on happiness & $\begin{array}{ll}\text { - } & \text { very happy } \\
\text { - } & \text { a little bit happy } \\
\text { - } & \text { not happy }\end{array}$ \\
\hline Michels et al., 2019 [42] & How they mostly feel (Feeling of happiness) & From 0 (not at all) to 10 (very strong) \\
\hline Minkkinen et al., 2015 [82] & $\begin{array}{l}\text { All things considered, how happy would you say } \\
\text { you are? }\end{array}$ & $\begin{array}{l}\text { From } 1 \text { (extremely unhappy) to } 10 \\
\text { (extremely happy) }\end{array}$ \\
\hline Moljord et al., 2011 [125] & $\begin{array}{l}\text { How happy or pleased have you been during the } \\
\text { last week? }\end{array}$ & $\begin{array}{ll}\text { - } & \text { extremely unhappy } \\
\text { - } & \text { very unhappy } \\
\text { - } & \text { quite unhappy } \\
\text { - } & \text { moderately unhappy } \\
\text { - } & \text { a little unhappy } \\
\text { - } & \text { neutral } \\
\text { - } & \text { a little happy } \\
\text { - } & \text { moderately happy } \\
\text { - } & \text { quite happy } \\
\text { - } & \text { very happy } \\
\text { - } & \text { extremely happy } \\
\text { taken from the Fordyce Happiness Scale } \\
\text { (short version) }\end{array}$ \\
\hline
\end{tabular}

Fat et al., 2016 [141]

Participants were asked to rate how happy they were.

Ngamaba, 2016 [126]

Park et al., 2014 [62]

Do you think you are living happily now?
Taking all things together, would you say you are

From 0 (unhappy) to 10 (happy)

- not at all happy

- not very happy

- quite happy

- very happy

From 1 (strongly disagree) to 5 (strongly agree)

- $\quad$ very happy

- happy

- average

- unhappy

- $\quad$ very unhappy

- very happy

- happy

- $\quad$ average

- unhappy

- $\quad$ very unhappy

From 1 (completely happy) to 7 (not at all happy) based on 'smiley' faces

\begin{tabular}{ll} 
Peasgood et al., 2016 [63] & Happiness with their life overall \\
\hline Phongsavan et al., 2010 [128] & Perceived happiness with life in general \\
\hline $\begin{array}{l}\text { Powdthavee and Vernoit, 2014 } \\
\text { [129] }\end{array}$ & How happy they feel about their life as a whole
\end{tabular}

Unspecified

From 1 (completely unhappy) to 7 (completely happy)

- all the time

- very often

- often

- rarely

- $\quad$ very rarely

- never

$-$

\begin{tabular}{lll}
\hline Saarikallio et al., 2016 [43] & I generally feel happy. & - \\
\hline Sfreddo et al., 2018 [130] & $\begin{array}{l}\text { How satisfied are you with your life, all things } \\
\text { considered? }\end{array}$ & $\begin{array}{l}\text { From 1 to 7 (higher-better), taken from } \\
\text { the Subjective Happiness Scale (SHS) }\end{array}$ \\
\hline
\end{tabular}


Table A3. Cont.

\begin{tabular}{|c|c|c|}
\hline Study & Question & Response Options \\
\hline Shiue, 2012 [107] & Subjective happiness & $\begin{array}{ll}\text { - } & \text { very happy } \\
\text { - } & \text { happy } \\
\text { - } & \text { unhappy } \\
\text { - } & \text { very unhappy }\end{array}$ \\
\hline Sithey et al., 2016 [154] & Subjective well-being was assessed. & $\begin{array}{l}\text { From } 0 \text { (not a very happy person) to } 10 \text { (a } \\
\text { very happy person) }\end{array}$ \\
\hline So and Yeo, 2015 [155] & Subjective happiness level & $\begin{array}{ll}\text { - } & \text { unhappy } \\
\text { - } & \text { average } \\
\text { - } & \text { happy }\end{array}$ \\
\hline Spithoven et al., 2016 [147] & How happy do you feel in general? & $\begin{array}{l}\text { From } 0 \text { (very unhappy) to } 10 \text { (very } \\
\text { happy) in a visual analogue scale }\end{array}$ \\
\hline Twenge and Campbell, 2019 [88] & $\begin{array}{l}\text { Taking all things together, how would you say } \\
\text { things are these days? Would you say these days } \\
\text { you're: }\end{array}$ & $\begin{array}{ll}\text { - } & \text { very happy } \\
\text { - } & \text { pretty happy } \\
\text { - } & \text { not too happy }\end{array}$ \\
\hline Vaishnav et al., 2018 [45] & Not specified & Faces scale \\
\hline Van Aart et al., 2018 [66] & Recent feelings of happiness & $\begin{array}{l}\text { From } 0 \text { to } 10 \text { Likert scale (highest to } \\
\text { lowest) }\end{array}$ \\
\hline van Campen et al., 2012 [149] & $\begin{array}{l}\text { To what extent do you regard yourself as a } \\
\text { happy person? }\end{array}$ & $\begin{array}{ll}\text { - } & \text { unhappy } \\
\text { - } & \text { not very happy } \\
\text { - } & \text { neither happy nor unhappy } \\
\text { - } & \text { happy } \\
\text { - } & \text { very happy }\end{array}$ \\
\hline Viner et al., 2019 [131] & Overall, how happy did you feel yesterday? & From 0 (minimal) to 10 (high) \\
\hline Wang et al., 2015 [132] & $\begin{array}{l}\text { Taking all things together, would you say you } \\
\text { are happy? }\end{array}$ & $\begin{array}{l}\text { From } 1 \text { (very happy) to } 4 \text { (not at all } \\
\text { happy) }\end{array}$ \\
\hline Whitehead et al., 2017 [156] & $\begin{array}{l}\text { In general, how do you feel about your life at } \\
\text { present? }\end{array}$ & $\begin{array}{ll}\text { - } & \text { I'm not happy at all } \\
\text { - } & \text { I don't feel very happy } \\
\text { - } & \text { I feel quite happy } \\
\text { - } & \text { I feel very happy }\end{array}$ \\
\hline Yadav et al., 2017 [35] & Feeling of happiness & $\begin{array}{l}\text { - constant: occurs on daily basis. } \\
\text { - } \quad \text { regular: occurs on less than daily } \\
\text { basis but more than once a week. } \\
\text { occasionally: occurs once or less } \\
\text { than once a week but more than } \\
\text { once a month. } \\
\text { - } \quad \text { rarely: occurs once or less than once } \\
\text { a month. } \\
\text { never: no occurrence. }\end{array}$ \\
\hline Yi and Kim, 2017 [134] & Subjective happiness & From 1 to 5 \\
\hline Yoo et al., 2013 [157] & Level of happiness (past 2 weeks) & $\begin{array}{ll}\text { - } & \text { very much } \\
\text { - } & \text { much } \\
\text { - } & \text { moderately } \\
\text { - } & \text { slightly } \\
\text { - } & \text { never }\end{array}$ \\
\hline Yu et al., 2011 [135] & All things considered, you are: & $\begin{array}{ll}\text { - } & \text { not happy at all } \\
\text { - } & \text { not very happy } \\
\text { - } & \text { happy } \\
\text { - } & \text { very happy }\end{array}$ \\
\hline Yu et al., 2012 [136] & All things considered, you are: & $\begin{array}{l}\text { - } \quad \text { not happy at all } \\
\text { - } \\
\text { - } \\
\text { - } \\
\text { happy very happy } \\
\text { very happy }\end{array}$ \\
\hline
\end{tabular}




\section{Appendix D}

Table A4. Studies using the happiness scales and their internal consistency.

\begin{tabular}{|c|c|c|c|}
\hline Questionnaire & $\begin{array}{l}\text { Questionnaire } \\
\text { Authors }\end{array}$ & Study & Internal Consistency \\
\hline \multirow{24}{*}{$\begin{array}{l}\text { Subjective Happiness Scale } \\
\text { (SHS) }\end{array}$} & \multirow{24}{*}{$\begin{array}{l}\text { Lyubomirsky and } \\
\text { Lepper, } 1999 \text { [3] }\end{array}$} & Bartels et al., 2010 [91] & - \\
\hline & & Burrow and Hill, 2011 [70] & Standardized $\alpha=0.83$ \\
\hline & & de Bruin et al., 2011 [139] & $\alpha=0.74$ \\
\hline & & Veronese et al., 2011 [89] & - \\
\hline & & Bartels et al., 2013 [91] & $\alpha=0.84$ \\
\hline & & Brasseur et al., 2013 [49] & $\alpha=0.80$ \\
\hline & & da Rosa et al., 2015 [158] & - \\
\hline & & Disabato et al., 2015 [53] & - \\
\hline & & Haworth et al., 2015 [78] & $\alpha=0.79$ \\
\hline & & Yeung et al., 2015 [133] & $\alpha=0.80$ \\
\hline & & Sheldon et al., 2015 [44] & - \\
\hline & & Tuchtenhagen et al., 2015 [160] & - \\
\hline & & Barke et al., 2016 [36] & $\alpha=0.88$ \\
\hline & & Brailovskaia and Margraf, 2016 [48] & $\alpha=0.82$ \\
\hline & & Dai and Chu, 2016 [73] & $\alpha=0.71$ \\
\hline & & Langer et al., 2016 [79] & - \\
\hline & & Salavera et al., 2017 [84] & $\alpha=0.845$ \\
\hline & & Wootton et al., 2017 [108] & $\alpha=0.79$ \\
\hline & & Bremer et al., 2018 [69] & $\begin{array}{l}\text { The average internal consistency } \\
\text { of the measure was } \alpha=0.74 \\
\text { across the } 3 \text { timepoints. }\end{array}$ \\
\hline & & Lai et al., 2018 [121] & $\begin{array}{l}\text { Cronbach's } \alpha \text { of the } 3 \text { items was } \\
0.87 \text {. }\end{array}$ \\
\hline & & Shen et al., 2018 [85] & $\alpha=0.81$ \\
\hline & & Ferrer-Cascales et al., 2019 [95] & $\alpha=0.75$ \\
\hline & & Freire and Ferreira, 2019 [4] & $\alpha=0.79$ \\
\hline & & Zhao et al., 2019 [138] & $\alpha=0.68$ \\
\hline \multirow{7}{*}{$\begin{array}{l}\text { Oxford Happiness } \\
\text { Questionnaire (OHQ) }\end{array}$} & \multirow{7}{*}{$\begin{array}{l}\text { Hills and Argyle, } 2002 \\
\text { [161] }\end{array}$} & Garaigordobil, 2015 [77] & $\alpha=0.86$ \\
\hline & & Heizomi et al., 2015 [56] & - \\
\hline & & Maganto et al., 2016 [123] & $\alpha=0.86$ \\
\hline & & Ataeiasl et al., 2018 [12] & - \\
\hline & & Hezomi and Nadrian, 2018 [56] & - \\
\hline & & Fariddanesh and Rezaei, 2019 [140] & $\alpha=0.88$ \\
\hline & & Guerra-Bustamante et al., 2019 [97] & $\alpha=0.800$ \\
\hline
\end{tabular}


Table A4. Cont.

\begin{tabular}{|c|c|c|c|}
\hline Questionnaire & $\begin{array}{l}\text { Questionnaire } \\
\text { Authors }\end{array}$ & Study & Internal Consistency \\
\hline \multirow{5}{*}{$\begin{array}{l}\text { The Oxford Happiness } \\
\text { Questionnaire-Short Form } \\
\text { (OHQ-sf) }\end{array}$} & \multirow{5}{*}{$\begin{array}{l}\text { Hills and Argyle, } 2002 \\
\text { [161] }\end{array}$} & López-Pérez and Wilson, 2015 [40] & $\alpha=0.75$ \\
\hline & & Su et al., 2012 [148] & $\alpha=0.87$ \\
\hline & & Su et al., 2017 [87] & $\alpha=0.87$ \\
\hline & & Lung et al., 2019 [144] & $\begin{array}{l}\text { The analysis of the reliability of } \\
\text { the revised 7-item questionnaire } \\
\text { resulted in a Cronbach's alpha of } \\
0.63 \text {. }\end{array}$ \\
\hline & & Lung and Shu, 2019 [159] & $\begin{array}{l}\text { The reliability analysis of the } 8 \\
\text { items resulted in a Chronbach's } \\
\text { alpha of } 0.499 \text {. However, item } \\
\text { statistics showed that if item } \\
\text { number } 7 \text { "I feel fully mentally } \\
\text { alert" was deleted, the } \\
\text { Chronbach's alpha would } \\
\text { increase to } 0.629 \text {. }\end{array}$ \\
\hline
\end{tabular}

\begin{tabular}{ll} 
Meleddu et al., 2012 [124] & $\alpha=0.90$ \\
\hline Choi et al., 2014 [92] & $\alpha=0.92$ \\
\hline Abdollahi et al., 2016 [68] & - \\
\hline
\end{tabular}

Cronbach's alpha was good for Satisfaction with life ( 6 items; $\alpha=$ 0.77 ), Mastery (10 items; $\alpha=0.75$ )

Oxford Happiness Inventory $(\mathrm{OHI})$

Argyle et al., 1989 [162] and Social cheerfulness (5 items; $\alpha=0.74)$, sufficient for Vigor (5 items; $\alpha=0.63$ ), and poor for Social Interest ( 2 items; $\alpha=0.57$ ). The omega coefficient was good for Satisfaction with life $(\omega=$ $0.98)$, Mastery $(\omega=0.92)$, Vigor $(\omega$ $=0.93)$, and Social Cheerfulness $(\omega=0.97)$, and sufficient for Social Interest $(\omega=0.75)$. $-$

\begin{tabular}{ll} 
Mehrdadi et al., 2016 [103] & - \\
\hline Booker et al., 2014 [110] & $\alpha=0.77$
\end{tabular}

[no definite name]

Chan and Koo, 2011

Kelly et al., 2016 [142] $\alpha=0.83$
[163]

Cronbach's alpha for children with ASD $=0.79$ and children without $\mathrm{ASD}=0.83$.

\begin{tabular}{llll}
\hline Pemberton Happiness Index & $\begin{array}{l}\text { Hervás and Vázquez, } \\
\text { 2013 [22] }\end{array}$ & Hervás and Vázquez, 2013 [22] & Range $\alpha=0.82-0.93$ \\
\hline $\begin{array}{l}\text { The Humboldt Happiness } \\
\begin{array}{l}\text { Scale-Adolescent Version } \\
\text { (HHSAV) }\end{array}\end{array}$ & Reynolds, 2005 [164] & Pandya, 2017 [106] & $\alpha=0.95$ \\
\hline $\begin{array}{l}\text { The Happiness Measures } \\
\text { (HM) }\end{array}$ & Fordyce, 1998 [165] & Lemes et al., 2018 [152] & - \\
\hline $\begin{array}{l}\text { Gross National Happiness } \\
\begin{array}{l}\text { Abridged Survey (GNHAS) } \\
\text { questionnaire }\end{array}\end{array}$ & $\begin{array}{l}\text { Pennock and Ura, 2012 } \\
\text { [166] }\end{array}$ & Vogler et al., 2014 [67] & - \\
\hline
\end{tabular}


Table A4. Cont.

\begin{tabular}{|c|c|c|c|}
\hline Questionnaire & $\begin{array}{l}\text { Questionnaire } \\
\text { Authors }\end{array}$ & Study & Internal Consistency \\
\hline WHO-5 Well-being Index & $\begin{array}{l}\text { World Health } \\
\text { Organization, } 1998 \text { [21] }\end{array}$ & Abdel-Khalek, 2011 [46] & - \\
\hline [no definite name] & Han, 2011 [180] & Choi et al., 2019 [51] & $\alpha=0.902$ \\
\hline [no definite name] & Quy, 2019 [64] & Quy et al., 2019 [64] & $\alpha=0.61$ \\
\hline [no definite name] & $\begin{array}{l}\text { Schacter and Margolin, } \\
2019 \text { [65] }\end{array}$ & Schacter and Margolin, 2019 [65] & $\begin{array}{l}\text { The happiness measure had good } \\
\text { within-person }(\alpha=0.70) \text { and } \\
\text { between-person }(\alpha=0.78) \\
\text { reliability. }\end{array}$ \\
\hline
\end{tabular}

\section{Appendix E}

Table A5. Studies using the happiness subscales and their internal consistency.

\begin{tabular}{|c|c|c|c|c|c|}
\hline Scale & Version & $\begin{array}{l}\text { Author(s), } \\
\text { Year }\end{array}$ & Subscales & $\begin{array}{c}\text { Internal } \\
\text { Consistency }\end{array}$ & Study \\
\hline \multirow{5}{*}{$\begin{array}{l}\text { Piers-Harris } \\
\text { Children's } \\
\text { Self-Concept } \\
\text { Scale (PHC-SCS) }\end{array}$} & \multirow{4}{*}{$\begin{array}{l}\text { Piers-Harris } \\
\text { Children's } \\
\text { Self-Concept } \\
\text { Scale }\end{array}$} & \multirow{4}{*}{$\begin{array}{l}\text { Piers and } \\
\text { Harris, } 1963 \\
{[167]}\end{array}$} & \multirow{4}{*}{$\begin{array}{l}\text { Behavior, Intellectual and } \\
\text { School Status, Physical } \\
\text { Appearance and Attributes, } \\
\text { Anxiety, Popularity, and } \\
\text { Happiness and Satisfaction }\end{array}$} & - & $\begin{array}{l}\text { Bolat et al., } 2011 \\
{[23]}\end{array}$ \\
\hline & & & & - & $\begin{array}{l}\text { Lázaro et al., } 2011 \\
\text { [38] }\end{array}$ \\
\hline & & & & - & $\begin{array}{l}\text { Murphy et al., } 2013 \\
\text { [60] }\end{array}$ \\
\hline & & & & - & Liu et al., 2017 [39] \\
\hline & $\begin{array}{l}\text { Piers-Harris } \\
2 \text { Children's } \\
\text { Self-Concept } \\
\text { Scale }\end{array}$ & $\begin{array}{l}\text { Piers and } \\
\text { Herzberg, } 2002 \\
{[168]}\end{array}$ & $\begin{array}{l}\text { Behavioral Adjustment, } \\
\text { Intellectual and School Status, } \\
\text { Physical Appearance and } \\
\text { Attributes, Freedom from } \\
\text { Anxiety, Popularity, and } \\
\text { Happiness and Satisfaction }\end{array}$ & - & $\begin{array}{l}\text { Oriel et al., } 2012 \\
\text { [61] }\end{array}$ \\
\hline \multirow{4}{*}{$\begin{array}{l}\text { Profile of Mood } \\
\text { States (POMS) }\end{array}$} & \multirow{3}{*}{$\begin{array}{l}\text { Profile of } \\
\text { Mood States } \\
\text { question- } \\
\text { naire }\end{array}$} & \multirow{3}{*}{$\begin{array}{l}\text { McNair et al., } \\
1971 \text { [169] }\end{array}$} & $\begin{array}{l}\text { Daily happiness subscale } \\
\text { (happy, joy, and calm) }\end{array}$ & $\alpha=0.88$ & $\begin{array}{l}\text { Potochnick et al., } \\
2012 \text { [24] }\end{array}$ \\
\hline & & & $\begin{array}{l}\text { Happiness: joyful, happy, and } \\
\text { calm; Distress: sad, hopeless, } \\
\text { and discouraged; and Anxiety: } \\
\text { on edge, uneasy, and nervous }\end{array}$ & $\alpha=0.86$ & $\begin{array}{l}\text { Kiang and } \\
\text { Buchanan, } 2013 \\
\text { [99] }\end{array}$ \\
\hline & & & $\begin{array}{l}\text { Happiness (joyful, happy, and } \\
\text { calm) and Distress (sadness, } \\
\text { hopeless, discouraged, on } \\
\text { edge, unable to concentrate, } \\
\text { uneasy, and nervous) }\end{array}$ & $\begin{array}{l}\alpha_{\text {Wave1 }}=0.68-0.75 \\
\alpha_{\text {Wave2 }}=0.68-0.76\end{array}$ & $\begin{array}{l}\text { Mercado et al., } \\
2019 \text { [104] }\end{array}$ \\
\hline & $\begin{array}{l}\text { Adolescent } \\
\text { version } \\
\text { (POMS-A) }\end{array}$ & $\begin{array}{l}\text { Terry et al., } \\
1999 \text { [170] }\end{array}$ & $\begin{array}{l}\text { Adolescents responded to two } \\
\text { items each for depressed } \\
\text { mood (i.e., DEPRESSED, SAD, } \\
\text { or BLUE), anxious mood (i.e., } \\
\text { WORRIED or SCARED), } \\
\text { angry mood (i.e., ANGRY or } \\
\text { ANNOYED), and positive } \\
\text { mood (i.e., HAPPY or } \\
\text { CONTENT). }\end{array}$ & - & $\begin{array}{l}\text { Fosco and } \\
\text { Lydon-Staley, } 2019 \\
\text { [54] }\end{array}$ \\
\hline
\end{tabular}


Table A5. Cont.

\begin{tabular}{|c|c|c|c|c|}
\hline Version & $\begin{array}{l}\text { Author(s), } \\
\text { Year }\end{array}$ & Subscales & $\begin{array}{c}\text { Internal } \\
\text { Consistency }\end{array}$ & Study \\
\hline \multirow{4}{*}{$\begin{array}{l}\text { EPOCH measure of Adolescent } \\
\text { Well-Being }\end{array}$} & \multirow{4}{*}{$\begin{array}{l}\text { Kern et al., } \\
2016 \text { [57] }\end{array}$} & \multirow{4}{*}{$\begin{array}{l}\text { EPOCH Measure of } \\
\text { Adolescent Well-Being, which } \\
\text { assesses five positive } \\
\text { psychological characteristics } \\
\text { (Engagement, Perseverance, } \\
\text { Optimism, Connectedness, } \\
\text { and Happiness) }\end{array}$} & - & $\begin{array}{l}\text { Kern et al., } 2015 \\
{[57]}\end{array}$ \\
\hline & & & $\begin{array}{l}\text { Reliability } \\
\text { coefficient of } 0.89, \\
95 \% \text { CI }(0.89,0.90)\end{array}$ & $\begin{array}{l}\text { Loton and Waters, } \\
2017 \text { [122] }\end{array}$ \\
\hline & & & - & $\begin{array}{l}\text { Giacomo et al., } \\
2019 \text { [55] }\end{array}$ \\
\hline & & & - & $\begin{array}{l}\text { Zeng and Kern, } \\
2019 \text { [137] }\end{array}$ \\
\hline \multirow{3}{*}{$\begin{array}{l}\text { Daily Mood Scale, an Internet } \\
\text { version of the Electronic Mood } \\
\text { Device }\end{array}$} & \multirow{3}{*}{$\begin{array}{l}\text { Hoeksma et al., } \\
2000[171]\end{array}$} & \multirow{3}{*}{$\begin{array}{l}\text { Happiness (glad, happy, and } \\
\text { cheerful), anger (angry, cross, } \\
\text { and short-tempered), anxiety } \\
\text { (afraid, anxious, and worried), } \\
\text { and sadness (sad, down, and } \\
\text { dreary) }\end{array}$} & $\begin{array}{l}\text { Cronbach's } \alpha \mathrm{s} \\
\text { ranged from } 0.86 \\
\text { to } 0.94 \text { for } \\
\text { happiness }\end{array}$ & $\begin{array}{l}\text { Neumann et al., } \\
2011 \text { [105] }\end{array}$ \\
\hline & & & $\begin{array}{l}\text { Cronbach's } \alpha \text { s } \\
\text { ranged from } 0.86 \\
\text { to } 0.96 \text { for } \\
\text { happiness }\end{array}$ & $\begin{array}{l}\text { Maciejewski et al., } \\
2015 \text { [80] }\end{array}$ \\
\hline & & & $\begin{array}{l}\text { Cronbach's } \alpha \text { s } \\
\text { ranged from } 0.86 \\
\text { to } 0.96 \text { for } \\
\text { happiness }\end{array}$ & $\begin{array}{l}\text { Maciejewski et al., } \\
2016 \text { [102] }\end{array}$ \\
\hline \multirow{2}{*}{$\begin{array}{l}\text { Positive and } \\
\text { Negative Affect } \\
\text { Scale }\end{array}$} & \multirow{2}{*}{$\begin{array}{l}\text { Laurent et al., } \\
1999 \text { [172] }\end{array}$} & $\begin{array}{l}\text { Unique moderated subscales } \\
\text { (four emotional states: } \\
\text { happiness, anticipation, } \\
\text { sadness, and anger) }\end{array}$ & - & $\begin{array}{l}\text { Chao et al., } 2018 \\
\text { [71] }\end{array}$ \\
\hline & & $\begin{array}{l}\text { Unique moderated subscales } \\
\text { (Daily happiness: Happy, } \\
\text { Cheerful, Joyful, Delighted, } \\
\text { and Excited) }\end{array}$ & - & $\begin{array}{l}\text { Moore et al., } 2019 \\
\text { [83] }\end{array}$ \\
\hline
\end{tabular}

\section{References}

1. Waterman, A.S. Two conceptions of happiness: Contrasts of personal expressiveness (eudaimonia) and hedonic enjoyment. J. Pers. Soc. Psychol. 1993, 64, 678-691. [CrossRef]

2. Kraut, R. Two conceptions of happiness. Philos. Rev. 1979, 88, 167-197. [CrossRef]

3. Lyubomirsky, S.; Lepper, H. A measure of subjective happiness: Preliminary reliability and construct validation. Soc. Indic. Res. 1999, 46, 137-155. [CrossRef]

4. Freire, T.; Ferreira, G. Do I need to be positive to be happy? Considering the role of self-esteem, life satisfaction, and psychological distress in Portuguese adolescents' subjective happiness. Psychol. Rep. 2020, 123, 1064-1082. [CrossRef]

5. Helliwell, J.; Layard, R.; Sachs, J. World Happiness Report; The Earth Institute, Columbia University: New York, NY, USA, 2021; Available online: https:/ /open.library.ubc.ca/media/stream/pdf/52383/1.0053622/3 (accessed on 13 January 2022).

6. Steptoe, A. Happiness and health. Annu. Rev. Public Health 2019, 40, 339-359. [CrossRef] [PubMed]

7. Tan, H.; Luo, J.; Zhang, M. Higher Education, Happiness, and Residents' Health. Front. Psychol. 2020, 11, 1669. [CrossRef] [PubMed]

8. Frey, B.S.; Stutzer, A. Happiness: A New Approach in Economics. CESifo DICE Rep. 2010, 8, 3-7, ISSN 1613-6373. Available online: https:/ / www.econstor.eu/bitstream/10419/167014/1/ifo-dice-report-v08-y2010-i4-p03-07.pdf (accessed on 13 January 2022).

9. Otsuka, Y.; Kaneita, Y.; Itani, O.; Jike, M.; Osaki, Y.; Higuchi, S.; Kanda, H.; Kinjo, A.; Kuwabara, Y.; Yoshimoto, H. The relationship between subjective happiness and sleep problems in Japanese adolescents. Sleep Med. 2020, 69, 120-126. [CrossRef]

10. Hoyt, L.T.; Chase-Lansdale, P.L.; McDade, T.W.; Adam, E.K. Positive youth, healthy adults: Does positive well-being in adolescence predict better perceived health and fewer risky health behaviors in young adulthood? J. Adolesc. Health 2012 50, 66-73. [CrossRef]

11. Chen, J.; Ho, S.Y.; Leung, L.T.; Wang, M.P.; Lam, T.H. Associations of unhappiness with sociodemographic factors and unhealthy behaviours in Chinese adolescents. Eur. J. Public Health 2017, 27, 518-524. [CrossRef] 
12. Ataeiasl, M.; Sarbakhsh, P.; Dadashzadeh, H.; Augner, C.; Anbarlouei, M.; Mohammadpoorasl, A. Relationship between happiness and tobacco smoking among high school students. Epidemiol. Health 2018, 40, e2018009. [CrossRef] [PubMed]

13. Keyes, C.L. The mental health continuum: From languishing to flourishing in life. J. Health Soc. Behav. 2002, 43, 207-222. [CrossRef] [PubMed]

14. Diener, E. Subjective well-being: The science of happiness and a proposal for a national index. Am. Psychol. 2000, 55, 34-43. [CrossRef] [PubMed]

15. Beyens, I.; Pouwels, J.L.; van Driel, I.I.; Keijsers, L.; Valkenburg, P.M. The effect of social media on well-being differs from adolescent to adolescent. Sci. Rep. 2020, 10, 10763. [CrossRef]

16. Hong, J.E.; Kim, M. Effects of a psychological management program on subjective happiness, anger control ability, and gratitude among late adolescent males in Korea. Int. J. Environ. Res. Public Health 2020, 17, 2683. [CrossRef]

17. Ruiz-Ariza, A.; la Torre-Cruz, D.; Manuel, J.; Appelqvist-Schmidlechner, K.; Tamminen, N.; Martínez-López, E.J. Does physical fitness and parenting transformational style predict happiness and well-being and distress in adolescents? Retos 2020, 38, 626-631. [CrossRef]

18. Talaeizadeh, F. Comparison of Acceptance Commitment Therapy (ACT) and Cognitive Behavioral Therapy (CBT) in Reducing Depression symptoms and Increasing Happiness of Iranian adolescent Girl Students. J. Intellect. Disabil. Diagn. Treat. 2020, 8, 16-24. [CrossRef]

19. Taheri, Z. Studying the Effect of Classroom Interior Design on the Happiness and Mental Health of the Female Adolescent Students. J. Biochem. Technol. 2019, 10, 138-148.

20. Cheon, H.; Lim, S. Pursuing Sustainable Happiness through Participation in Exercise for South Korean Students: Structural Relationships among Exercise, Mental Health Factors, School Satisfaction, and Happiness. Sustainability 2020, 12, 3797. [CrossRef]

21. WHO. Well-Being Measures in Primary Health Care/The Depcare Project. WHO Regional Office for Europe: Copenhagen. 1998. Available online: https:/ / www.euro.who.int/_data/assets/pdf_file/0016/130750/E60246.pdf (accessed on 13 January 2022).

22. Hervás, G.; Vázquez, C. Construction and validation of a measure of integrative well-being in seven languages: The Pemberton Happiness Index. Health Qual. Life Outcomes 2013, 11, 66. [CrossRef] [PubMed]

23. Bolat, N.; Dogangun, B.; Yavuz, M.; Demir, T.; Kayaalp, L. Depression and anxiety levels and self-concept characteristics of adolescents with congenital complete visual impairment. Turk. Psikiyatr. Derg. 2011, 22, 77-83.

24. Potochnick, S.; Perreira, K.M.; Fuligni, A. Fitting in: The roles of social acceptance and discrimination in shaping the daily psychological well-being of Latino youth. Soc. Sci. Q. 2012, 93, 173-190. [CrossRef]

25. Proctor, C.L.; Linley, P.A.; Maltby, J. Youth life satisfaction: A review of the literature. J. Happiness Stud. 2009, 10, 583-630. [CrossRef]

26. Cooke, P.J.; Melchert, T.P.; Connor, K. Measuring well-being: A review of instruments. Couns. Psychol. 2016, 44, 730-757. [CrossRef]

27. Hutton, B.; Catala-Lopez, F.; Moher, D. The PRISMA statement extension for systematic reviews incorporating network metaanalysis: PRISMA-NMA. Med. Clin. 2016, 147, 262-266. [CrossRef] [PubMed]

28. Sanderson, S.; Tatt, I.D.; Higgins, J. Tools for assessing quality and susceptibility to bias in observational studies in epidemiology: A systematic review and annotated bibliography. Int. J. Epidemiol. 2007, 36, 666-676. [CrossRef] [PubMed]

29. Zeng, X.; Zhang, Y.; Kwong, J.S.; Zhang, C.; Li, S.; Sun, F.; Niu, Y.; Du, L. The methodological quality assessment tools for preclinical and clinical studies, systematic review and meta-analysis, and clinical practice guideline: A systematic review. $J$. Evid.-Based Med. 2015, 8, 2-10. [CrossRef] [PubMed]

30. Ma, L.L.; Wang, Y.Y.; Yang, Z.H.; Huang, D.; Weng, H.; Zeng, X.T. Methodological quality (risk of bias) assessment tools for primary and secondary medical studies: What are they and which is better? Mil. Med. Res. 2020, 7, 7. [CrossRef] [PubMed]

31. Wells, G.A.; Shea, B.; O'Connell, D.; Peterson, J.; Welch, V.; Losos, M.; Tugwell, P. The Newcastle-Ottawa Scale (NOS) for Assessing the Quality of Nonrandomised Studies in Meta-Analyses. 2000. Available online: http://www.ohri.ca/programs/clinical_ epidemiology/oxford.asp (accessed on 13 January 2022).

32. National Heart, Lung, and Blood Institute. Study Quality Assessment Tools. Available online: https://www.nhlbi.nih.gov/ health-topics/study-quality-assessment-tools (accessed on 13 January 2022).

33. CASP Checklist. Available online: https:// casp-uk.net/casp-tools-checklists/ (accessed on 13 January 2022).

34. Islamova, S.N.; Islamov, R.S. Prediction of Risk for Boys' Involvement in Drug Use Based on Levels of Self-evaluations in Russia. Indian J. Psychol. Med. 2017, 39, 281-286. [CrossRef]

35. Yadav, P.; Nunia, S.; Bansal, A.; Sureka, S.K.; Jena, R.; Ansari, M.S.; Srivastava, A. Multidimensional assessment of quality of life of children and problems of parents in Indian society after pediatric renal transplant: Beyond the conventional thoughts. Pediatr. Transplant. 2017, 21, e13001. [CrossRef] [PubMed]

36. Barke, J.; Coad, J.; Harcourt, D. The role of appearance in adolescents' experiences of neurofibromatosis type 1: A survey of young people and parents. J. Genet. Couns. 2016, 25, 1054-1062. [CrossRef]

37. Chen, L.H.; Chen, M.Y.; Tsai, Y.M. Does gratitude always work? Ambivalence over emotional expression inhibits the beneficial effect of gratitude on well-being. Int. J. Psychol. 2012, 47, 381-392. [CrossRef] [PubMed]

38. Lázaro, L.; Font, E.; Moreno, E.; Calvo, R.; Vila, M.; Andrés-Perpiñá, S.; Canalda, G.; Martínez, E.; Castro-Fornieles, J. Effectiveness of self-esteem and social skills group therapy in adolescent eating disorder patients attending a day hospital treatment programme. Eur. Eat. Disord. Rev. 2011, 19, 398-406. [CrossRef] 
39. Liu, L.F.; Bian, Q.T.; Zhai, J.G. Analysis of psychological characteristics of obese children. Eur. Rev. Med. Pharmacol. Sci. 2017, $21,2665-2670$.

40. López-Pérez, B.; Wilson, E.L. Parent-child discrepancies in the assessment of children's and adolescents' happiness. J. Exp. Child Psychol. 2015, 139, 249-255. [CrossRef] [PubMed]

41. Maher, C.A.; Toohey, M.; Ferguson, M. Physical activity predicts quality of life and happiness in children and adolescents with cerebral palsy. Disabil. Rehabil. 2016, 38, 865-869. [CrossRef] [PubMed]

42. Michels, N.; Van de Wiele, T.; Fouhy, F.; O'Mahony, S.; Clarke, G.; Keane, J. Gut microbiome patterns depending on children's psychosocial stress: Reports versus biomarkers. Brain Behav. Immun. 2019, 80, 751-762. [CrossRef]

43. Saarikallio, S.; Gold, C.; McFerran, K. Development and validation of the Healthy-Unhealthy Music Scale. Child Adolesc. Ment. Health 2015, 20, 210-217. [CrossRef] [PubMed]

44. Sheldon, K.M.; Jose, P.E.; Kashdan, T.B.; Jarden, A. Personality, effective goal-striving, and enhanced well-being: Comparing 10 candidate personality strengths. Pers. Soc. Psychol. Bull. 2015, 41, 575-585. [CrossRef] [PubMed]

45. Vaishnav, B.S.; Vaishnav, S.B.; Vaishnav, V.S.; Varma, J.R. Effect of yoga-nidra on adolescents well-being: A mixed method study. Int. J. Yoga 2018, 11, 245-248. [CrossRef]

46. Abdel-Khalek, A.M. Subjective well-being and religiosity in Egyptian college students. Psychol. Rep. 2011, 108, 54-58. [CrossRef] [PubMed]

47. Abdel-Khalek, A.M. Religiosity, health and happiness: Significant relations in adolescents from Qatar. Int. J. Soc. Psychiatry 2014, 60, 656-661. [CrossRef]

48. Brailovskaia, J.; Margraf, J. Comparing Facebook users and Facebook non-users: Relationship between personality traits and mental health variables-an exploratory study. PLoS ONE 2016, 11, e0166999. [CrossRef]

49. Brasseur, S.; Grégoire, J.; Bourdu, R.; Mikolajczak, M. The profile of emotional competence (PEC): Development and validation of a self-reported measure that fits dimensions of emotional competence theory. PLoS ONE 2013, 8, e62635. [CrossRef]

50. Cebotari, V.; Mazzucato, V.; Appiah, E. A longitudinal analysis of well-being of Ghanaian children in transnational families. Child Dev. 2018, 89, 1768-1785. [CrossRef] [PubMed]

51. Choi, Y.S.; Shin, H.K.; Hong, D.Y.; Kim, J.R.; Kang, Y.S.; Jeong, B.; Park, K.S.; Lee, K.H. Self-esteem as a Moderator of the Effects of Happiness, Depression, and Hostility on Suicidality Among Early Adolescents in Korea. J. Prev. Med. Public Health 2019, 52, 30-40. [CrossRef]

52. Deserno, M.K.; Borsboom, D.; Begeer, S.; Geurts, H.M. Multicausal systems ask for multicausal approaches: A network perspective on subjective well-being in individuals with autism spectrum disorder. Autism 2017, 21, 960-971. [CrossRef] [PubMed]

53. Disabato, D.J.; Goodman, F.R.; Kashdan, T.B.; Short, J.L.; Jarden, A. Different types of well-being? A cross-cultural examination of hedonic and eudaimonic well-being. Psychol. Assess. 2016, 28, 471-482. [CrossRef]

54. Fosco, G.M.; Lydon-Staley, D.M. Implications of Family Cohesion and Conflict for Adolescent Mood and Well-Being: Examining Within- and Between- Family Processes on a Daily Timescale. Fam. Process 2019, 59, 1672-1689. [CrossRef]

55. Giacomo, D.; Ranieri, J.; Fiasca, F.; Mattei, A. Lifestyle, body mass index and wellness in youth: Strengthens and weakness in Italian youth. Health Psychol. Res. 2019, 7, 8035. [CrossRef] [PubMed]

56. Hezomi, H.; Nadrian, H. What determines psychological well-being among Iranian female adolescents? Perceived stress may overshadow all determinants. Health Promot. Perspect. 2018, 8, 79-87. [CrossRef]

57. Kern, M.L.; Benson, L.; Steinberg, E.A.; Steinberg, L. The EPOCH measure of adolescent well-being. Psychol. Assess. 2016, 28, 586-597. [CrossRef]

58. Lee, G.; Ham, O.K.; Lee, B.G.; Kim, A.M. Differences in factors associated with depressive symptoms between urban and rural female adolescents in Korea. J. Korean Acad. Nurs. 2018, 48, 475-484. [CrossRef] [PubMed]

59. Mahfoud, Z.; Abdulrahim, S.; Taha, M.B.; Harpham, T.; El Hajj, T.; Makhoul, J.; Nakkash, R.; Kanj, M.; Afifi, R. Validation of the Arab Youth Mental Health scale as a screening tool for depression/anxiety in Lebanese children. Child Adolesc. Psychiatry Ment. Health 2011, 5, 9. [CrossRef]

60. Murphy, D.A.; Marelich, W.D.; Graham, J.; Payne, D.L. Children affected by maternal HIV / AIDS: Feasibility and acceptability trial of the Children United with Buddies (CUB) intervention. Clin. Child Psychol. Psychiatry 2015, 20, 117-133. [CrossRef] [PubMed]

61. Oriel, K.N.; Marchese, V.G.; Shirk, A.; Wagner, L.; Young, E.; Miller, L. The psychosocial benefits of an inclusive community-based aquatics program. Pediatr. Phys. Ther. 2012, 24, 361-367. [CrossRef] [PubMed]

62. Park, M.; Choi, J.; Lim, S.J. Factors affecting aggression in South Korean middle school students. Asian Nurs. Res. 2014, 8, 247-253. [CrossRef]

63. Peasgood, T.; Bhardwaj, A.; Biggs, K.; Brazier, J.E.; Coghill, D.; Cooper, C.L.; Daley, D.; De Silva, C.; Harpin, V.; Nadkarni, A.; et al. The impact of ADHD on the health and well-being of ADHD children and their siblings. Eur. Child Adolesc. Psychiatry 2016, 25, 1217-1231. [CrossRef]

64. Quy, K.; Gibb, J.; Neil, L.; Smith, M. Development and Preliminary Validation of a Self-Report Coping Response Measure in a Community Sample of Children in Middle Childhood. J. Pers. Assess. 2019, 102, 628-640. [CrossRef]

65. Schacter, H.L.; Margolin, G. The interplay of friends and parents in adolescents' daily lives: Towards a dynamic view of social support. Soc. Dev. 2019, 28, 708-724. [CrossRef] 
66. Van Aart, C.J.; Michels, N.; Sioen, I.; De Decker, A.; Bijnens, E.M.; Janssen, B.G.; De Henauw, S.; Nawrot, T.S. Residential landscape as a predictor of psychosocial stress in the life course from childhood to adolescence. Environ. Int. 2018, 120, 456-463. [CrossRef] [PubMed]

67. Vogler, J.; Klein, A.M.; Bender, A. Long-term health-related quality-of-life in patients with acquired brain injury and their caregivers. Brain Inj. 2014, 28, 1381-1388. [CrossRef]

68. Abdollahi, A.; Talib, M.A.; Motalebi, S.A. Emotional intelligence and depressive symptoms as predictors of happiness among adolescents. Iran. J. Psychiatry Behav. Sci. 2015, 9, e2268. [CrossRef] [PubMed]

69. Bremer, E.; Graham, J.D.; Veldhuizen, S.; Cairney, J. A program evaluation of an in-school daily physical activity initiative for children and youth. BMC Public Health 2018, 18, 1023. [CrossRef]

70. Burrow, A.L.; Hill, P.L. Purpose as a form of identity capital for positive youth adjustment. Dev. Psychol. 2011, 47, 1196-1206. [CrossRef]

71. Chao, C.C.; Chen, L.H.; Lin, Y.C.; Wang, S.H.; Wu, S.H.; Li, W.C.; Huang, K.-F.; Chiu, T.-F.; Kuo, I.C. Impact of a 3-Day HighAltitude Trek on Xue Mountain (3886 m), Taiwan, on the Emotional States of Children: A Prospective Observational Study. High Alt. Med. Biol. 2019, 20, 28-34. [CrossRef]

72. Correa-Velez, I.; Gifford, S.M.; McMichael, C. The persistence of predictors of well-being among refugee youth eight years after resettlement in Melbourne, Australia. Soc. Sci. Med. 2015, 142, 163-168. [CrossRef]

73. Dai, Q.; Chu, R.X. Anxiety, happiness and self-esteem of western Chinese left-behind children. Child Abuse Negl. 2018, 86, 403-413. [CrossRef]

74. Delgado, P.F.; Caamano-Navarrete, F.; Martinez-Salazar, C.; Jerez-Mayorga, D.; Carter-Thuiller, B.; García, F.P.; Latorre, P.R. Childhood obesity and its association with the feeling of unhappiness and low levels of self-esteem in children of public schools. Nutr. Hosp. 2018, 35, 533-537. [CrossRef]

75. Fararouei, M.; Brown, I.J.; Toori, M.A.; Haghighi, R.E.; Jafari, J. Happiness and health behaviour in Iranian adolescent girls. J. Adolesc. 2013, 36, 1187-1192. [CrossRef]

76. Farmer, S.; Hanratty, B. The relationship between subjective well-being, low income and substance use among schoolchildren in the north west of England: A cross-sectional study. J. Public Health 2012, 34, 512-522. [CrossRef] [PubMed]

77. Garaigordobil, M. Predictor variables of happiness and its connection with risk and protective factors for health. Front. Psychol. 2015, 6, 1176. [CrossRef]

78. Haworth, C.M.; Carter, K.; Eley, T.C.; Plomin, R. Understanding the genetic and environmental specificity and overlap between well-being and internalizing symptoms in adolescence. Dev. Sci. 2017, 20, e12376. [CrossRef] [PubMed]

79. Langer, Á.I.; Ulloa, V.G.; Aguilar-Parra, J.M.; Araya-Véliz, C.; Brito, G. Validation of a Spanish translation of the Gratitude Questionnaire (GQ-6) with a Chilean sample of adults and high schoolers. Health Qual. Life Outcomes 2016, 14, 53. [CrossRef]

80. Maciejewski, D.F.; van Lier, P.A.; Branje, S.J.; Meeus, W.H.; Koot, H.M. A 5-year longitudinal study on mood variability across adolescence using daily diaries. Child Dev. 2015, 86, 1908-1921. [CrossRef]

81. McChesney, G.; Toseeb, U. Happiness, self-esteem, and prosociality in children with and without autism spectrum disorder: Evidence from a UK population cohort study. Autism Res. 2018, 11, 1011-1023. [CrossRef] [PubMed]

82. Minkkinen, J.; Oksanen, A.; Näsi, M.; Keipi, T.; Kaakinen, M.; Räsänen, P. Does social belonging to primary groups protect young people from the effects of pro-suicide sites? Crisis 2015, 37, 31-41. [CrossRef] [PubMed]

83. Moore, C.C.; Hubbard, J.A.; Bookhout, M.K.; Mlawer, F. Relations between reactive and proactive aggression and daily emotions in adolescents. J. Abnorm. Child Psychol. 2019, 47, 1495-1507. [CrossRef]

84. Salavera, C.; Urcola-Pardo, F.; Usán, P.; Jarie, L. Translation and validation of the Mind-Wandering Test for Spanish adolescents. Psicol. Reflex. Crit. 2017, 30, 12. [CrossRef] [PubMed]

85. Shen, L.; van Schie, J.; Ditchburn, G.; Brook, L.; Bei, B. Positive and negative emotions: Differential associations with sleep duration and quality in adolescents. J. Youth Adolesc. 2018, 47, 2584-2595. [CrossRef]

86. Stiglbauer, B.; Gnambs, T.; Gamsjäger, M.; Batinic, B. The upward spiral of adolescents' positive school experiences and happiness: Investigating reciprocal effects over time. J. Sch. Psychol. 2013, 51, 231-242. [CrossRef] [PubMed]

87. Su, S.; Li, X.; Lin, D.; Zhu, M. Future orientation, social support, and psychological adjustment among left-behind children in rural China: A longitudinal study. Front. Psychol. 2017, 8, 1309. [CrossRef]

88. Twenge, J.M.; Campbell, W.K. Media use is linked to lower psychological well-being: Evidence from three datasets. Psychiatr. Q. 2019, 90, 311-331. [CrossRef] [PubMed]

89. Veronese, G.; Castiglioni, M.; Tombolani, M.; Said, M. My happiness is the refugee camp, my future Palestine': Optimism, life satisfaction and perceived happiness in a group of Palestinian children. Scand. J. Caring Sci. 2012, 26, 467-473. [CrossRef] [PubMed]

90. Ali, A.; Ambler, G.; Strydom, A.; Rai, D.; Cooper, C.; McManus, S.; Weich, S.; Meltzer, H.; Dein, S.; Hassiotis, A. The relationship between happiness and intelligent quotient: The contribution of socio-economic and clinical factors. Psychol. Med. 2013, 43, 1303-1312. [CrossRef] [PubMed]

91. Bartels, M.; Cacioppo, J.T.; van Beijsterveldt, T.C.; Boomsma, D.I. Exploring the association between well-being and psychopathology in adolescents. Behav. Genet. 2013, 43, 177-190. [CrossRef] [PubMed]

92. Choi, J.H.; Yu, M.; Kim, K.E. Suicidal ideation in adolescents: A structural equation modeling approach. Nurs. Health Sci. 2015, 17, 119-125. [CrossRef] 
93. Du, H.; Chi, P.; King, R.B. Economic Inequality is Associated with Long-Term Harm on Adolescent Well-Being in China. Child Dev. 2019, 90, 1016-1026. [CrossRef]

94. Fadda, D.; Scalas, L.F. Neuroticism as a moderator of direct and mediated relationships between introversion-extraversion and well-being. Eur. J. Psychol. 2016, 12, 49-67. [CrossRef]

95. Ferrer-Cascales, R.; Albaladejo-Blázquez, N.; Ruiz-Robledillo, N.; Clement-Carbonell, V.; Sánchez-SanSegundo, M.; Zaragoza-Martí, A. Higher Adherence to the Mediterranean Diet is Related to More Subjective Happiness in Adolescents: The Role of Health-Related Quality of Life. Nutrients 2019, 11, 698. [CrossRef]

96. Fischer, J.A.; Najman, J.M.; Plotnikova, M.; Clavarino, A.M. Quality of life, age of onset of alcohol use and alcohol use disorders in adolescence and young adulthood: Findings from an Australian birth cohort. Drug Alcohol Rev. 2015, 34, 388-396. [CrossRef] [PubMed]

97. Guerra-Bustamante, J.; León-del-Barco, B.; Yuste-Tosina, R.; López-Ramos, V.M.; Mendo-Lázaro, S. Emotional intelligence and psychological well-being in adolescents. Int. J. Environ. Res. Public Health 2019, 16, 1720. [CrossRef]

98. Heizomi, H.; Allahverdipour, H.; Jafarabadi, M.A.; Safaian, A. Happiness and its relation to psychological well-being of adolescents. Asian J. Psychiatry 2015, 16, 55-60. [CrossRef]

99. Kiang, L.; Buchanan, C.M. Daily stress and emotional well-being among Asian American adolescents: Same-day, lagged, and chronic associations. Dev. Psychol. 2014, 50, 611-621. [CrossRef] [PubMed]

100. Lardon, C.; Wolsko, C.; Trickett, E.; Henry, D.; Hopkins, S. Assessing health in an Alaska native cultural context: The Yup'ik Wellness Survey. Cultur. Divers. Ethnic Minor. Psychol. 2016, 22, 126-136. [CrossRef]

101. Lin, W.H.; Pan, W.C.; Yi, C.C. Happiness in the air? The effects of air pollution on adolescent happiness. BMC Public Health 2019, 19, 795. [CrossRef]

102. Maciejewski, D.F.; van Lier, P.A.; Branje, S.J.; Meeus, W.H.; Koot, H.M. A daily diary study on adolescent emotional experiences: Measurement invariance and developmental trajectories. Psychol. Assess. 2017, 29, 35-49. [CrossRef] [PubMed]

103. Mehrdadi, A.; Sadeghian, S.; Direkvand-Moghadam, A.; Hashemian, A. Factors affecting happiness: A cross-sectional study in the Iranian youth. J. Clin. Diagn. Res. 2016, 10, VC01. [CrossRef] [PubMed]

104. Mercado, E.; Kim, J.; Gonzales, N.A.; Fuligni, A.J. Emotional Coregulation in Mexican-Origin Parent-Adolescent Dyads: Associations with Adolescent Mental Health. J. Youth Adolesc. 2019, 48, 1116-1130. [CrossRef] [PubMed]

105. Neumann, A.; Van Lier, P.A.; Frijns, T.; Meeus, W.; Koot, H.M. Emotional dynamics in the development of early adolescent psychopathology: A one-year longitudinal study. J. Abnorm. Child Psychol. 2011, 39, 657-669. [CrossRef]

106. Pandya, S.P. Spirituality, Happiness, and Psychological Well-being in 13-to 15-year olds: A Cross-country Longitudinal RCT Study. J. Pastor. Care Couns. 2017, 71, 12-26. [CrossRef]

107. Shiue, I.V.Y. Neighbourhood satisfaction and happiness but not urbanization level affect self-rated health in adolescents. Scand. J. Public Health 2012, 40, 498-500. [CrossRef] [PubMed]

108. Wootton, R.E.; Davis, O.S.; Mottershaw, A.L.; Wang, R.A.H.; Haworth, C.M. Genetic and environmental correlations between subjective well-being and experience of life events in adolescence. Eur. Child Adolesc. Psychiatry 2017, 26, 1119-1127. [CrossRef] [PubMed]

109. Bartels, M.; Saviouk, V.; De Moor, M.H.; Willemsen, G.; van Beijsterveldt, T.C.; Hottenga, J.J.; de Geus, E.J.C.; Boomsma, D.I Heritability and genome-wide linkage scan of subjective happiness. Twin Res. Hum. Genet. 2010, 13, 135-142. [CrossRef] [PubMed]

110. Booker, C.L.; Skew, A.J.; Kelly, Y.J.; Sacker, A. Media use, sports participation, and well-being in adolescence: Cross-sectional findings from the UK household longitudinal study. Am. J. Public Health 2015, 105, 173-179. [CrossRef]

111. Borges, A.; de Matos, M.G.; Diniz, J.A. Body image and subjective well-being in Portuguese adolescents. Span. J. Psychol. 2013 [CrossRef]

112. Cho, M.S.; Kim, J.Y. A study of factors affecting the physical activity of youth: Analysis of data from the 13th youth health behavior online survey in 2017. J. Exerc. Rehabil. 2019, 15, 8-14. [CrossRef]

113. Cooper, C.; Bebbington, P.; King, M.; Jenkins, R.; Farrell, M.; Brugha, T.; McManus, S.; Stewart, R.; Livingston, G. Happiness across age groups: Results from the 2007 National Psychiatric Morbidity Survey. Int. J. Geriatr. Psychiatry 2011, 26, 608-614. [CrossRef]

114. Cosma, A.; Whitehead, R.; Neville, F.; Currie, D.; Inchley, J. Trends in bullying victimization in Scottish adolescents 1994-2014: Changing associations with mental well-being. Int. J. Public Health 2017, 62, 639-646. [CrossRef]

115. Dales, R.E.; Cakmak, S. Does mental health status influence susceptibility to the physiologic effects of air pollution? A population based study of Canadian children. PLoS ONE 2016, 11, e0168931. [CrossRef]

116. Fonseca, H.; Matos, M.G. Are adolescent weight-related problems and general well-being essentially an issue of age, gender or rather a pubertal timing issue? J. Pediatr. Endocrinol. Metab. 2011, 24, 251-256. [CrossRef] [PubMed]

117. Gaspar de Matos, M.; Simões, C.; Batista-Foguet, J.; Cottraux, J. Personal and social factors associated with the perception of health and the perception of happiness in a nonclinical adolescent population. Encephale 2009, 36, 39-45. [CrossRef] [PubMed]

118. González-Quiñones, J.C.; Restrepo-Chavarriaga, G. The prevalence of happiness in life-cycles and regarding support networks in the Colombian population. Rev. Salud Pública 2010, 12, 228-238. [CrossRef]

119. He, Z.; Cheng, Z.; Bishwajit, G.; Zou, D. Wealth inequality as a predictor of subjective health, happiness and life satisfaction among Nepalese women. Int. J. Environ. Res. Public Health 2018, 15, 2836. [CrossRef] [PubMed] 
120. Kelly, C.; Fitzgerald, A.; Sentenac, M.; Gakewski, J.; Molcho, M.; Gabhainn, S.N. Weight concerns among adolescent boys. Public Health Nutr. 2016, 19, 456-462. [CrossRef] [PubMed]

121. Lai, M.K.; Leung, C.; Kwok, S.Y.; Hui, A.N.; Lo, H.H.; Leung, J.T.; Tam, C.H. A multidimensional PERMA-H positive education model, general satisfaction of school life, and character strengths use in Hong Kong senior primary school students: Confirmatory factor analysis and path analysis using the APASO-II. Front. Psychol. 2018, 9, 1090. [CrossRef] [PubMed]

122. Loton, D.J.; Waters, L.E. The mediating effect of self-efficacy in the connections between strength-based parenting, happiness and psychological distress in teens. Front. Psychol. 2017, 8, 1707. [CrossRef]

123. Maganto, C.; Garaigordobil, M.; Kortabarria, L. Eating problems in adolescents and youths: Explanatory variables. Span. J. Psychol. 2016, 19, E81. [CrossRef]

124. Meleddu, M.; Guicciardi, M.; Scalas, L.F.; Fadda, D. Validation of an Italian version of the Oxford Happiness Inventory in adolescence. J. Pers. Assess. 2012, 94, 175-185. [CrossRef]

125. Moljord, I.E.O.; Eriksen, L.; Moksnes, U.K.; Espnes, G.A. Stress and happiness among adolescents with varying frequency of physical activity. Percept. Mot. Skills 2011, 113, 631-646. [CrossRef]

126. Ngamaba, K.H. Determinants of subjective well-being in representative samples of nations. Eur. J. Public Health 2017, 27, 377-382. [CrossRef]

127. Park, S.; Rim, S.J.; Lee, J.H. Associations between dietary behaviours and perceived physical and mental health status among Korean adolescents. Nutr. Diet. 2018, 75, 488-493. [CrossRef] [PubMed]

128. Phongsavan, P.; Smith, B.J.; Chey, T.; Gilmete, M.; Havea, D.; Bauman, A.E. Health Behaviour and Lifestyle of Pacific Youth Survey Collaborating Group and Tonga Core Survey Team. Psychosocial profiles of adolescent nonsmokers in the pacific. Asia-Pac. J. Public Health 2011, 23, 57-69. [CrossRef] [PubMed]

129. Powdthavee, N.; Vernoit, J. Parental unemployment and children's happiness: A longitudinal study of young people's well-being in unemployed households. Labour Econ. 2013, 24, 253-263. [CrossRef]

130. Sfreddo, C.S.; Moreira, C.H.C.; Celeste, R.K.; Nicolau, B.; Ardenghi, T.M. Pathways of socioeconomic inequalities in gingival bleeding among adolescents. Community Dent. Oral Epidemiol. 2019, 47, 177-184. [CrossRef]

131. Viner, R.M.; Gireesh, A.; Stiglic, N.; Hudson, L.D.; Goddings, A.L.; Ward, J.L.; Nicholls, D.E. Roles of cyberbullying, sleep, and physical activity in mediating the effects of social media use on mental health and well-being among young people in England: A secondary analysis of longitudinal data. Lancet Child Adolesc. Health 2019, 3, 685-696. [CrossRef]

132. Wang, X.; Jia, X.; Zhu, M.; Chen, J. Linking health states to subjective well-being: An empirical study of 5854 rural residents in China. Public Health 2015, 129, 655-666. [CrossRef]

133. Yeung, D.Y.; Ho, S.M.; Mak, C.W. Brief report: Attention to positive information mediates the relationship between hope and psychosocial well-being of adolescents. J. Adolesc. 2015, 42, 98-102. [CrossRef]

134. Yi, Y.; Kim, J.S. Korean adolescents' health behavior and psychological status according to their mother's nationality. Osong Public Health Res. Perspect. 2017, 8, 377-383. [CrossRef] [PubMed]

135. Yu, X.; Stewart, S.M.; Wong, P.T.; Lam, T.H. Screening for depression with the Patient Health Questionnaire-2 (PHQ-2) among the general population in Hong Kong. J. Affect. Disord. 2011, 134, 444-447. [CrossRef]

136. Yu, X.; Tam, W.W.; Wong, P.T.; Lam, T.H.; Stewart, S.M. The Patient Health Questionnaire-9 for measuring depressive symptoms among the general population in Hong Kong. Compr. Psychiatry 2012, 53, 95-102. [CrossRef] [PubMed]

137. Zeng, G.; Kern, M. The Chinese EPOCH measure of adolescent well-being: Further testing of the psychometrics of the measure. Front. Psychol. 2019, 16, e0259191. [CrossRef]

138. Zhao, J.; Li, Q.; Wang, L.; Lin, L.; Zhang, W. Latent profile analysis of left-behind adolescents' psychosocial adaptation in rural China. J. Youth Adolesc. 2019, 48, 1146-1160. [CrossRef] [PubMed]

139. De Bruin, E.I.; Zijlstra, B.J.; van de Weijer-Bergsma, E.; Bögels, S.M. The mindful attention awareness scale for adolescents (MAAS-A): Psychometric properties in a Dutch sample. Mindfulness 2011, 2, 201-211. [CrossRef] [PubMed]

140. Fariddanesh, M.; Rezaei, A.M. Predicting the happiness of adolescents based on coping styles and religious attitudes. J. Relig. Health 2019, 58, 537-553. [CrossRef] [PubMed]

141. Fat, L.N.; Scholes, S.; Boniface, S.; Mindell, J.; Stewart-Brown, S. Evaluating and establishing national norms for mental well-being using the short Warwick-Edinburgh Mental Well-being Scale (SWEMWBS): Findings from the Health Survey for England. Qual. Life Res. 2017, 26, 1129-1144. [CrossRef] [PubMed]

142. Kelly, Y.; Patalay, P.; Montgomery, S.; Sacker, A. BMI development and early adolescent psychosocial well-being: UK Millennium Cohort Study. Pediatrics 2016, 138, e20160967. [CrossRef]

143. Lim, M.S.C.; Cappa, C.; Patton, G.C. Subjective well-being among young people in five Eastern European countries. Glob. Ment. Health 2017, 4, E12. [CrossRef]

144. Lung, F.W.; Shu, B.C.; Chiang, T.L.; Lin, S.J. Prevalence of bullying and perceived happiness in adolescents with learning disability, intellectual disability, ADHD, and autism spectrum disorder: In the Taiwan Birth Cohort Pilot Study. Medicine 2019, 98, e14483. [CrossRef]

145. Park, S.; Lee, Y.; Jang, H.; Jo, M. Violence victimization in Korean adolescents: Risk factors and psychological problems. Int. J. Environ. Res. Public Health 2017, 14, 541. [CrossRef]

146. Richards, J.; Jiang, X.; Kelly, P.; Chau, J.; Bauman, A.; Ding, D. Don't worry, be happy: Cross-sectional associations between physical activity and happiness in 15 European countries. BMC Public Health 2015, 15, 53. [CrossRef] [PubMed] 
147. Spithoven, A.W.; Lodder, G.M.; Goossens, L.; Bijttebier, P.; Bastin, M.; Verhagen, M.; Scholte, R.H. Adolescents' loneliness and depression associated with friendship experiences and well-being: A person-centered approach. J. Youth Adolesc. 2017, 46, 429-441. [CrossRef]

148. Su, S.; Li, X.; Lin, D.; Xu, X.; Zhu, M. Psychological adjustment among left-behind children in rural China: The role of parental migration and parent-child communication. Child Care Health Dev. 2013, 39, 162-170. [CrossRef] [PubMed]

149. van Campen, C.; de Boer, A.H.; Iedema, J. Are informal caregivers less happy than noncaregivers? Happiness and the intensity of caregiving in combination with paid and voluntary work. Scand. J. Caring Sci. 2013, 27, 44-50. [CrossRef] [PubMed]

150. Hong, S.A.; Peltzer, K. Dietary behaviour, psychological well-being and mental distress among adolescents in Korea. Child Adolesc. Psychiatry Ment. Health 2017, 11, 56. [CrossRef]

151. Kye, S.Y.; Kwon, J.H.; Park, K. Happiness and health behaviors in South Korean adolescents: A cross-sectional study. Epidemiol. Health 2016, 38, e2016022. [CrossRef]

152. Lemes, D.C.M.; Câmara, S.G.; Alves, G.G.; Aerts, D. Body image satisfaction and subjective well-being among ninth-grade students attending state schools in Canoas, Brazil. Ciência Saúde Coletiva 2018, 23, 4289-4298. [CrossRef]

153. Levin, K.A. Glasgow smiles better: An examination of adolescent mental well-being and the 'Glasgow effect'. Public Health 2012, 126, 96-103. [CrossRef]

154. Sithey, G.; Wen, L.M.; Kelly, P.; Li, M. Association between sleep duration and self-reported health status: Findings from the Bhutan's gross National Happiness Study. J. Clin. Sleep Med. 2017, 13, 33-38. [CrossRef]

155. So, E.S.; Yeo, J.Y. Factors associated with early smoking initiation among Korean adolescents. Asian Nurs. Res. 2015, 9, 115-119. [CrossRef]

156. Whitehead, R.D.; Cosma, A.; Cecil, J.; Currie, C.; Currie, D.; Neville, F.; Inchley, J. Trends in the perceived body size of adolescent males and females in Scotland, 1990-2014: Changing associations with mental well-being. Int. J. Public Health 2018, 63, 69-80. [CrossRef]

157. Yoo, Y.S.; Cho, O.H.; Cha, K.S. Associations between overuse of the internet and mental health in adolescents. Nurs. Health Sci. 2014, 16, 193-200. [CrossRef]

158. da Rosa, G.N.; Del Fabro, J.P.; Tomazoni, F.; Tuchtenhagen, S.; Alves, L.S.; Ardenghi, T.M. Association of malocclusion, happiness, and oral health-related quality of life (OHRQoL) in schoolchildren. J. Public Health Dent. 2016, 76, 85-90. [CrossRef] [PubMed]

159. Lung, F.W.; Shu, B.C. The psychometric properties of the Chinese Oxford Happiness Questionnaire in Taiwanese adolescents: Taiwan Birth Cohort Study. Community Ment. Health J. 2020, 56, 135-138. [CrossRef]

160. Tuchtenhagen, S.; Bresolin, C.R.; Tomazoni, F.; da Rosa, G.N.; Del Fabro, J.P.; Mendes, F.M.; Antunes, J.L.F.; Ardenghi, T.M. The influence of normative and subjective oral health status on schoolchildren's happiness. BMC Oral Health 2015, 15, 15. [CrossRef] [PubMed]

161. Hills, P.; Argyle, M. The Oxford Happiness Questionnaire: A compact scale for the measurement of psychological well-being Personal. Individ. Differ. 2002, 33, 1073-1082. [CrossRef]

162. Argyle, M.; Martin, M.; Crossland, J. Happiness as a Function of Personality and Social Encounters. In Recent Advances in Social Psychology: An International Perspective; Forgas, J.P., Innes, J.M., Eds.; American Psychological Association: Washington, DC, USA, 1989; Volume 1, pp. 189-203.

163. Chan, T.W.; Koo, A. Parenting style and youth outcomes in the UK. Eur. Sociol. Rev. 2011, 27, 385-399. [CrossRef]

164. Reynolds, W.M. Measuring happiness in young adults: Psychometric characteristics of the Humboldt Happiness Scale. In Proceedings of the Annual Meeting of the Society for Personality Assessment, Midwinter Scientific Exchange Workshops, Chicago, IL, USA, 2-6 March 2005.

165. Fordyce, M.W. A review of research on the happiness measures: A sixty second index of happiness and mental health. Soc. Indic. Res. 1988, 20, 355-381. [CrossRef]

166. Pennock, M.; Ura, D.K. The Gross National Happiness Abridged Survey; Theme: Global Standards and Local Diversity 2012. Available online: http://gnh-movement.org/papers/pennock.pdf (accessed on 18 January 2022).

167. Piers, E.; Harris, D. Children's Self Concept Scale. Recordings and Tests 1963. Available online: https://www.gvsu.edu/cms4 /asset/903124DF-BD7F-3286-FE3330AA44F994DE/Piers--Harris_childrens_self_concept_scale.pdf (accessed on 18 January 2022)

168. Piers, E.V.; Herzberg, D.S. Manual for the Piers-Harris Children's Self-Concept Scale, 2nd ed.; Western Psychological Services: Los Angeles, CA, USA, 2002.

169. McNair, D.M.; Lorr, M.; Droppleman, L.F. EITS Manual for the Profile of Mood States; Educational and Industrial Testing Service: San Diego, CA, USA, 1971.

170. Terry, P.C.; Lane, A.M.; Lane, H.J.; Keohane, L. Development and validation of a mood measure for adolescents. J. Sports Sci. 1999, 17, 861-872. [CrossRef] [PubMed]

171. Hoeksma, J.B.; Sep, S.M.; Vester, F.C.; Groot, P.F.C.; Sijmons, R.; deVries, J. The electronic mood device: Design, construction and application. Behav. Res. Methods Instrum. Comput. 2000, 32, 322-326. [CrossRef]

172. Laurent, J.; Catanzaro, S.J.; Joiner, T.E., Jr.; Rudolph, K.D.; Potter, K.I.; Lambert, S.; Osborne, L.; Gathright, T. A measure of positive and negative affect for children: Scale development and preliminary validation. Psychol. Assess. 1999, 11, 326-338. [CrossRef]

173. Ryan, R.M.; Deci, E.L. On happiness and human potentials: A review of research on hedonic and eudaimonic well-being. Annu. Rev. Psychol. 2001, 52, 141-166. [CrossRef]

174. Steptoe, A.; Deaton, A.; Stone, A.A. Subjective wellbeing, health, and ageing. Lancet 2015, 385, 640-648. [CrossRef] 
175. Si, S.X.; Cullen, J.B. Response categories and potential cultural bias: Effects of an explicit middle point in cross-cultural surveys. Int. J. Organ. Anal. 1998, 6, 218-230. [CrossRef]

176. Rieffe, C. Awareness and regulation of emotions in deaf children. Br. J. Dev. Psychol. 2012, 30, 477-492. [CrossRef] [PubMed]

177. Maurer, M.M.; Daukantaitè, D.; Hoff, E. Testing the psychometric properties of the Swedish version of the EPOCH measure of adolescent well-being. PLoS ONE 2021, 16, e0259191. [CrossRef] [PubMed]

178. Ortiz, F.R.; Paiva, S.M.; Pordeus, I.A.; Ardenghi, T.M. Psychometric properties and longitudinal measurement invariance of the Brazilian version of the subjective happiness scale in adolescents. J. Clin. Transl. Res. 2021, 7, 234-240. [CrossRef]

179. Yaklin, S.; Jain, R.; Cole, S.P.; Raison, C.; Rolin, D.; Jain, S. HERO Wellness Scale: Examining a new mental wellness scale. Ann. Psychiatry Clin. Neurosci. 2020, 32, 33-40.

180. Han, S.M. The Effects of Degree of Home-Environmental Well-Being on Adolescent's Emotional Intelligence, Social Intelligence and Happiness. Ph.D. Thesis, Inha University, Incheon, Korea, 2011. 